\title{
Landscape, Monumentality and Expression of Group Identities in Iron Age and Roman east Kent
}

\author{
By Lacey Wallace and Alex Mullen
}

\begin{abstract}
The Canterbury Hinterland Project (CHP) has combined aerial photographic and LiDAR analysis, synthesis of HER and other data across east Kent with targeted survey south and east of Canterbury. We present possible hillforts, temples, large enclosures, a major trackway, linking paths, burials, and high-status Roman-period complexes and argue that people organized the landscape to communicate meaning in two main ways: a 'public' face oriented towards the Dover-Canterbury road and expressions of ritual and remembrance for local groups. The character of this rural population has traditionally been understood in terms of its relationship to the civitas capital and villas, we look beyond this to examine a more detailed vision of possible social interactions.
\end{abstract}

Keywords:

aerial photography, Canterbury, geophysical survey, Iron Age and Roman Kent, landscape, memory, power, ritual, settlement, social organization

\section{INTRODUCTION}

Social structure and group identities are expressed in a variety of materially visible ways, including modification of the landscape, which perhaps receives less attention from Romanists than its scale, ubiquity, and scope for comparative study merit. Developments over time and a continual accretion of features make landscape a powerful medium (and form of material culture) through which to explore social constructs in Iron Age (IA) and Roman Britain. Physical and symbolic connections between settlement, burial, ritual sites and natural features reflect these constructs and can be studied through a consideration of how people in the past created and understood meaning through structures and movement in the landscape. Manipulations of temporality, for example, can be seen in the deliberate construction of relationships between earlier features of the Bronze Age/IA and Roman-period burial monuments and, by relating them 
to other landscape features and aspects of visibility and symbolic connections, we can begin to uncover the links between identity construction, communication, and belief. ${ }^{1}$

Kent provides evidence of complex changes to social structure and organization in the LPRIA and Roman-period. The relationship between the pre-Roman and Roman groupings has been a subject for external commentary since the first century BC when Caesar remarked that four rulers controlled ei qui Cantium incolunt 'those who live in Cantium' (B.G. V.22). Modern scholars tend to turn to the Roman 'civitas capital', Durovernum (Canterbury), in reconstructions of the tribal organization of Kent, assuming a key focus for IA settlement there and/or a sanctuary which may have united multiple LPRIA groups. ${ }^{2}$ They also regularly mention the stark difference in the distribution and density of high-status Roman-period structural complexes ('villas') between the west and the east/south of the modern county. In the Darent and Medway valleys, northwest and nearer to Londinium, 'villa'-type architecture is particularly well documented and high-status Roman-period buildings on sites with IA occupation levels (e.g. the mid-first-century $\mathrm{AD}$ villa building overlying an IA settlement at Eccles, or the development of villa buildings on a site with round houses at Thurnham) provide evidence that perhaps the local elite in the western part of Kent were early adopters of new architectural forms. ${ }^{3}$ In the east such sites are found in lower numbers and primarily on the coast, and not, apparently, in close proximity to Durovernum. This difference in distribution has been taken as a reflection of dissimilarities between groups of people also evident in earlier periods in the distributions of coinage, pottery, burial sites and a perceived lack of hillforts/oppida in the east. ${ }^{4}$ These discussions of Roman Britain lose much of the regional patterning in synthesis. We suggest that an exploration of how landscapes of settlement, burial and ritual created and communicated group identities, social hierarchies, and ties between people and place can help to further our understanding of the communities in Kent immediately before and during the Roman period. In this article, we focus in particular on the hinterland of Canterbury, where the relative lack of archaeological investigations has had a distorting effect on interpretations.

The CHP has combined extensive analysis of aerial photography and LiDAR from across east Kent, with results of earlier investigations and new multiple-technique geophysical surveys over several sites in the hinterland of Canterbury (Figure 1). The results

1 British prehistorians, for example Tilley (e.g. 1994), have been at the forefront of research into landscape and lived experience, particularly using phenomenological interpretive and theoretical frameworks. For overviews and criticisms of these endeavours see, for example, Brück 2005; Hamilton and Whitehouse 2006; Robb 1998. Romanists have generally been less enthusiastic to explore phenomenological approaches and tend to undertake work restricted to landscape investigations when these are focused on settlement. The edited volume Ritual Landscapes of Roman South-East Britain (Rudling 2008) does not explore ritual landscapes per se, but rather shrines, temples, sanctuaries, votive and epigraphic remains found in rural contexts. 2 For 'Belgic' settlement, see Detsicas 1983, 38-39; for the sanctuary origins hypothesis, see Millett 2007, 158-159 and Mattingly 2006, 271.

3 For IA Eccles, see Detsicas 1989; for Thurnham, see Lawrence 2006.

4 For recent work on hillfort distribution, see the Hillforts Atlas Project, https://hillforts.arch.ox.ac.uk/ [last accessed $23^{\text {rd }}$ December 2017]. 
have revealed evidence for settlement (three large, probably IA, enclosures which may represent previously unknown hillforts; multiple IA and Roman-period enclosures; a high-status Roman-period 'villa'-type building; a possible Roman-period provisioning centre; an IA/Roman-period nucleated settlement), burial (numerous Bronze Age to Saxon barrows; a probable LPRIA cemetery), ritual (several Roman-period temples) and movement (trackways, pathways, roads). ${ }^{5}$ This has led to the identification of a group based in the territory of the Nailbourne hilltop enclosure (?hillfort) in Bourne Park/ Bridge (Figure 2). The group appears to have used landscape features to communicate status and group identities, connecting people in a more complex network of features and 'places' than the traditional focus on high-status sites in isolation might suggest. We argue that they have made the landscape communicate meaning in two main ways: a 'public' face of power oriented towards the Dover to Canterbury road route and a more local or rural expression of ritual and remembrance.

This high-resolution analysis of the hinterland of Canterbury, where power, belief, and memory intersected in the symbolic connections between people and the landscape, allows us to see the social interactions in higher definition than presented in works of synthesis. The complex and long-term development of meaning found within this case study area draws from across the Bronze Age to the Roman period and demonstrates that the binding values imbued in the landscape, and reinforced through the movement and presence of people, could be durable and potent.

\section{SOCIAL ORGANIZATION IN KENT}

The 'hillfort' landscape and social patterning of IA Kent are still poorly understood. Though IA Kent is often grouped with the whole of south-east England in generalizing discussions, it looks rather different from the so-called 'hillfort zone' further to the west. In Kent, hillforts can be tentatively dated to the Middle and LPRIA (generally starting and finishing later than elsewhere), ${ }^{6}$ do not often provide evidence for dense occupation and may be positioned on the fringes of habitation. Here, perhaps even more than elsewhere, the connotations which attach themselves to 'fort' may be misleading and we have to be aware of a possible range of functions beyond a central defended place within a hierarchically dependent landscape. It has generally been assumed that western Kent contains a larger number of hillforts, with well-known examples at Oldbury, Tonbridge and Tunbridge Wells. ${ }^{7}$ Until recently, east Kent could only offer 'one proven

5 Wallace et al. 2016 presents a report of the 2011-2014 survey seasons at Bourne Park. The smaller survey areas at Patrixbourne, Ickham/Wingham, Petham (part of our investigations into the context for the Swarling cemetery, not shown on Figure 1), and Goodnestone will appear in future publications. In the meantime, please contact the authors for further information.

6 As Bates's recent doctoral thesis shows (Bates 2017), more research must be done using modern techniques to try to improve our dating of the hillforts.

7 For Oldbury, see Thompson 1986; for Tonbridge, see Money 1975, 1978; for Tunbridge Wells, see Money 1960, 1968. 


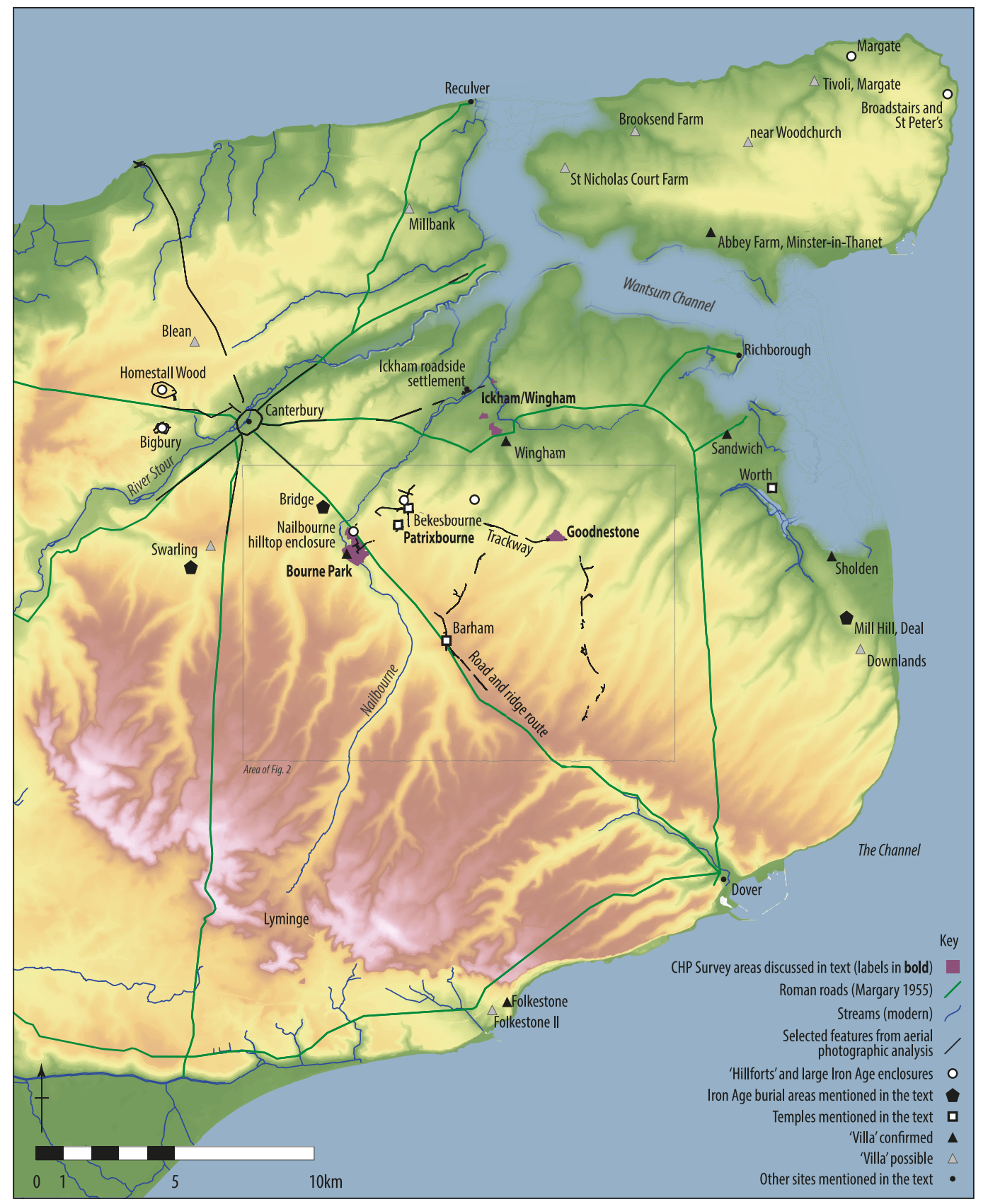

Figure 1. DEM of east Kent showing sites mentioned in the text, the CHP survey areas, selected features identified through the aerial photographic and geophysical surveys, the likely 'villas' from Blanning's (2014) core dataset of rural settlement sites, Roman roads, likely Iron Age 'hillforts' and large enclosures, Iron Age burial areas, and major streams. (Lacey Wallace and Chris Blair-Myers with Kent Historic Environment record data, DEM data (Crown copyright) database right 2017, an Ordnance Survey/EDINA supplied service), Roman roads from the Pleiades Project database (licensed under Creative Commons CC-BY 3.0), streams containing Environment Agency information (C) Environment Agency and database right.) 


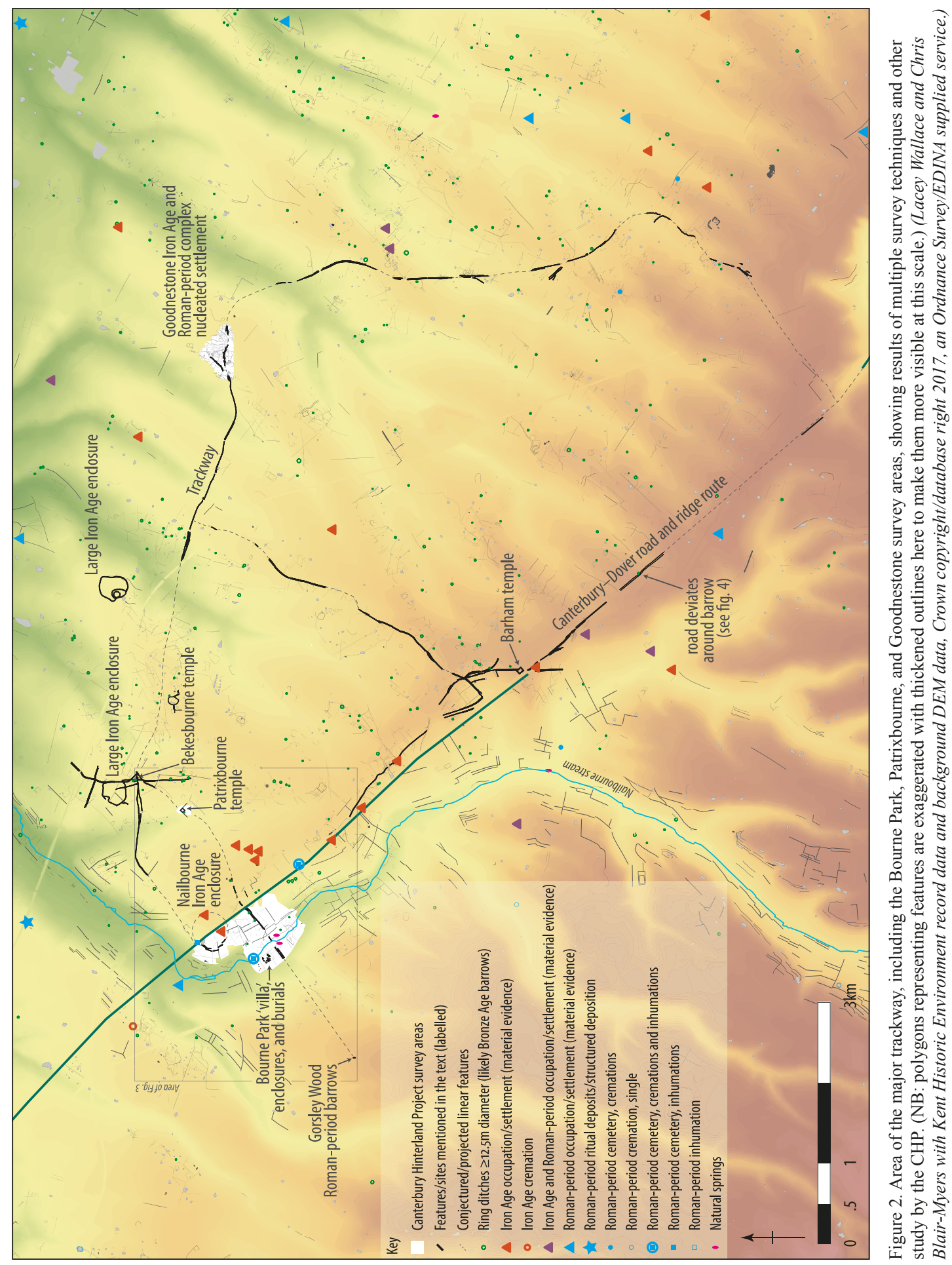


hillfort'- Bigbury/Bigberry near Canterbury (Figure 1). ${ }^{8}$ This 15 ha site is positioned to the west of Canterbury overlooking the river Stour and seems to have been in use from approximately the third century $\mathrm{BC}$ to the first century AD. If Bigbury served as a defensive location, or one from which to control the movement of people, the group/ individual who built/controlled Bigbury may have 'controlled' a $6 \mathrm{~km}$ stretch along the ridge southwest of the hillfort and to the north as far as what becomes Watling Street (a possible 'territory' of at least 700ha). ${ }^{9}$ It has generally been thought to be a precursor to pre-Roman Canterbury, but the precise function of the site is still debated, with some rejecting the traditional notion of an elite residence and promoting possible ritual functions,${ }^{10}$ and the relationship with LPRIA Canterbury cannot be ascertained on current evidence. Indeed, new evidence for other possible hillforts in the area has recently come to light and should be added to the ongoing debate on social patterning in ancient Kent. A hillfort at Homestall Wood, Harbledown, has been identified through LiDAR imagery, ${ }^{11}$ sited on elevated land on the other side of a tributary of the Stour west of Canterbury, opposite Bigbury (Figure 1). The period of occupation is not yet securely known, but finds associated with the site suggest that it was (still?) in use in the LPRIA. Many of these sites have only been identified, or better understood, in recent years and much work remains to be done to understand the implications of our newly populated vision of the occupied landscape of east Kent.

In general terms, Kent, like the rest of the south-east, underwent significant social change in the LPRIA, in part as a result of close connections across the Channel and the coming of Rome. ${ }^{12}$ One of the changes which is thought to characterize occupation in the south-east is the abandonment of hillforts and the creation of enclosed/unenclosed oppida, which tend to have characteristics such as extensive dyke systems, non-hilltop locations, dense occupation and town-like economic functions. Since several hillforts in Kent extend into the LPRIA and the nomenclature of large LPRIA settlements and their defining characteristics are not agreed, it is hard to be sure which sites should be classed as oppida. Champion identifies five: Canterbury, Rochester, Quarry Wood camp

8 Champion 2007, 119. For Bigbury, see Blockley and Blockley 1989; Jessup and Cook 1936; Thompson 1983.

9 For the recent work on Bigbury and the extent of its possible territory, see Bates 2017; Booth 2009, 276; Booth 2012, 350-351; Sparey-Green 2013.

10 For deposition of serviceable metalwork as possible ritual deposits at the time of the abandonment of Bigbury, see Ashbee 2005, 160; pace Thompson 1983 who republished the metalwork and discounted 'ritual explanations' of the material remains, preferring to see them as abandoned possessions of the inhabitants.

11 For Homestall Wood hillfort, see Sparey-Green 2010.

12 For LPRIA changes in the southeast, for example, coin minting and use, changing burial behaviour, emerging centres of social focus, and adoption of new material culture, see Champion 2016; Cunliffe 2005, 125-177. For this transformation beyond Kent seen through a range of evidence, see Creighton 2000 and 2006; Wallace 2016. 
(Loose) ${ }^{13}$ Bigbury and Oldbury, but these, like the hillforts more generally, develop differently and may have served varied functions. ${ }^{14}$ The occupied landscape of LPRIA Kent seems to have been heterogeneous. Since there was no systematic or imperially-defined method for people in Britain to follow to negotiate their status within the new Roman socio-political system, complex patterning in the rural landscape continues into the Roman period, though it is not necessarily of the same type. In some areas there is continuity of settlement without much change, in others continuity with radical changes, at least in form, and, in some areas, settlements are created on sites with little, or no, earlier activity. ${ }^{15}$

The major Kentish Roman centres have diverse trajectories of development and several indigenous sites where social power may have concentrated in the LPRIA seem to have been abandoned by, or during, the early years of the Roman conquest, including Bigbury. The features of IA and early Roman Canterbury do not neatly conform to the traditional conception of the development of a civitas capital, as, for example, typified by a centre such as Verulamium. The Ver Valley is marked by differentiation in farmstead sizes, extensive dyke systems, new cemeteries, and the prominently positioned elite burial at Folly Lane. ${ }^{16}$ The valley location that would accommodate Roman Canterbury (Durovernum Cantiacorum) offers evidence of settlement, enclosures, and coin minting, though without clear traces of the results of a perhaps more coercive hierarchy, as in the Ver valley. ${ }^{17}$ From the IA features, especially in the area that becomes the later Roman temple/theatre area, Millett has argued that it probably developed as a cultic centre or sanctuary ${ }^{18} \mathrm{He}$ further suggests that Canterbury may have been chosen as the civitas centre by the Roman administration 'because the religious centre was a neutral meeting point where different tribal groups came together' ${ }^{19}$ Although the Roman administration and authors of our textual sources grouped the people of Kent together

13 For Loose, see Kelly 1971. See Howell 2014 for discussion of the IA and Roman activity at Furfield Quarry, a site $1.35 \mathrm{~km}$ from Quarry Wood camp. Furfield Quarry lies within earthworks that have been related to the so-called oppidum in a recent assessment, see Elsden 2006. The excavations described by Howell show that there was IA to Roman continuity adjacent to the Roman road and that the road followed 'an alignment already defined by the layout of the Late Iron Age landscape' and seemed 'intended to link a number of established rural "native" settlements' $(2014,63)$. The territory of the oppidum is hard to reconstruct but it is possible that it could be related to these later large landscape features making connections across the landscape.

14 Champion 2007, 121.

15 See Booth 2017, especially 59.

16 For Verulamium, see Niblett and Thompson 2005.

17 See, e.g., Blagg 1995, 8-9.

18 Millett 2007. The mid-first-century BC coin profile and later trajectory of development at the Marlowe car park site in Canterbury suggest that a LPRIA sanctuary may have preceded the monumental construction of the theatre and temple complex in the late first century AD, indicating continuity from the LPRIA. See Blockley et al. 1995; Creighton 2006, 145; Gruel and Haselgrove 2007, 255; Holman 2005. Springhead represents another important sanctuary site in the civitas, see Andrews et al. 2011a and 2011b, Barnett et al. 2011, Biddulph et al. 2011.

19 Millett 2007, 158. Compare Londinium for a possibly similar 'neutral' setting, Wallace 2014. 
as the 'Cantiaci' or 'Cantii', ${ }^{20}$ explorations of the LPRIA landscape around Canterbury suggest that there may have been several contemporaneous hillforts/enclosed oppida (e.g. at Bigbury, Homestall Wood and Bourne Park) which may reflect separate social groups and their 'territories', perhaps of different social groups, and that the Roman administration may have ignored and/or simplified pre-Roman social-territorial groupings. Cantium was positioned at a bustling nexus of interactions between the rest of Britain and the Continent and a neutral meeting point which did not 'belong' to a single social group may have been attractive. ${ }^{21}$

As we have seen, the 'hinterland' surrounding Canterbury is allegedly not home to high-status rural Roman-period settlements and various hypotheses have been provided to explain this settlement distribution. ${ }^{22}$ One could try to argue that perhaps the early lack of villas may be related to Canterbury's slow development, but even by the second century $\mathrm{AD}$, when the road network connected Canterbury to each of the well-developed port towns, ${ }^{23}$ and an influential and recognisably urban settlement was constructed, the urban elites still chose not to build villa-type architecture in the hinterland. The proposal that the local elite lived solely in Canterbury, rather than in lavish country houses, is further undermined by a lack of elaborate town-house architecture in the civitas capital. ${ }^{24}$ Andrews' suggestion that the presence of the military and classis Britannica acted to depress the local economy, resulting in the local elite not having the resources to expend on elaborate architecture, ${ }^{25}$ seems unlikely given the relatively small numbers and irregular occupation of troops present. Black's argument that east Kent was annexed by the Romans before the west, and that the west is then a zone of resistance populated by Gauls who bring their villa traditions to confiscated land, ${ }^{26}$ is not based on sufficient evidence and creates an overly schematized social distribution. Mattingly has suggested imperial ownership and investment in the case of the so-called 'villa' at Ickham

20 For Cantiaci, Cantii, Cantium, see Detsicas 1987; Rivet and Smith 1979, 299-300.

21 As at other civitas capitals such as Verulamium and Silchester, it was not until the Flavian period and later that an indisputable urban character was formed and the street grid, forum (probably - it remains unexcavated), and other key Roman urban features were constructed. It seems that transforming the site at Canterbury into an urban centre and translating wealth and power into new, imperially-recognisable forms may not have been a priority for the local people or the imperial authorities in the mid first century AD. For the archaeology of Roman Canterbury, see Blockley et al. 1995; Blockley, Sparks and Tatton-Brown 1997; Driver, Rady and Sparks 1990; Frere 1971; Frere et al. 1987; Frere and Stow 1983; Frere, Stow and Bennett 1982a and 1982b; Helm 2014; Helm and Rady 2010; Rady 2009.

22 See Wilkinson 2000 for villas in the Swale district. For a recent survey of Roman rural settlement in Kent, see Booth 2017. For analysis of rural settlement and life in Roman Kent, including discussion of villas, see the three volume thesis, Blanning 2014.

23 Possible villa complexes - for example, at coastal sites such as Folkestone, Minster-in-Thanet, Sandwich and Sholden - suggest that coastal trade routes may have been of greater importance to local elites than the civitas centre at Canterbury, at least at certain periods. For Folkestone, see Parfitt 2012; Winbolt 1925; for Minster-in-Thanet, see Archaeologia Cantiana for multiple articles, including Parfitt et al. 2008; for Sandwich, see Parfitt 1980; for Sholden, see Parfitt 2009.

24 On this point, see Blagg 1982, 56; Frere 1974, 301.

25 Andrews 2001, 25.

26 Black 1987, 9, 25, 82. 
(between Canterbury and Richborough, labelled 'Ickham/Wingham' on Figure 1), private non-civitas ownership in the northwest of the modern county, and a group representing the civitas of the Cantiaci in the northeast not interested in villa building. ${ }^{27}$ This characterization relies on Romano-centric concerns and the standard interpretation of the Ickham finds as an 'imperial villa', which may be overturned by current research. ${ }^{28}$ It seems that, in all these interpretations, endogenous concerns and local patterning have been underplayed. Blanning (2014), for example, has demonstrated that the choice of where to build a high-status complex may be closely linked to the geology of the area: the boundary between different bedrock geologies apparently being the factor with the highest correlation to villa distribution in Kent, strongly linked to the opportunity for mixed farming. ${ }^{29}$ No doubt a constantly changing mixture of environmental and local and external social factors will have determined the distribution of elaborated rural architecture.

Millett compellingly asserts that we should instead regard lack of investment in high-status architectural complexes in the hinterland of Canterbury as a cultural decision. ${ }^{30}$ It may not be that the local elites were missing from the landscapes or that they did not have adequate resources to build villas, but rather that they expressed prestige in other ways. ${ }^{31}$ Certainly, the LPRIA elite in the southeast seem to have communicated and constructed their status, at least in part, through burial (e.g. the first-century BC high-status burials of the so-called 'Aylesford-Swarling culture' and the 'warrior' burials and barrow mounds at Brisley Farm, Ashford, and Mill Hill, Deal ${ }^{32}$ and it is likely that in certain areas they continued to do so, ${ }^{33}$ choosing not to expend their wealth on new forms of masonry architecture. Roman-period burial mounds (e.g. around Canterbury and at Gorsley Wood, discussed below) and extensive extra-urban cemeteries and

27 Mattingly 2006, 386-387.

28 The CHP has been undertaking geophysical prospection in the Wingham/Ickham area and has uncovered intensive activity from the Bronze Age onwards. What has sometimes been labelled an 'imperial villa' at Ickham appears to be a nucleated centre, perhaps a provisioning centre or 'small town'. Please contact the authors for further information.

29 Blanning 2014 Vol. 2, 192-201.

30 Millett 2007, 170.

31 Millett $(2007,170)$ also highlights that it is not just the patchy distribution of villas across Kent that is noteworthy: villa owners in Kent seem particularly committed to bathhouses, but are not as interested in elaborating their buildings with mosaics and triclinia as elsewhere in Britain. This again may suggest a specificity in the way the inhabitants engaged in 'Roman' behaviours, perhaps valuing Roman-style bathing above high-status dining parties, which may be dissimilar to choices in other parts of the province.

32 For Aylesford-Swarling culture, see Birchall 1965; Bushe-Fox 1925; Cunliffe 2005, 151-159; Evans 1890; for the Ashford and Deal burials, see Parfitt 1995; Stevenson and Johnson 2004; Stevenson 2013. For LPRIA burials in Kent generally, see Champion 2007, 123-127; Hamilton 2007.

33 For this suggestion, see Booth 2017, 62, with reference to Northumberland Bottom. For the stunning first-century-AD burials uncovered there in the A2 excavations between Pepperhill and Cobham, see Allen at al. 2012. The two Brisley Farm 'warrior' burials can be dated to c. AD 10 and c. AD 40-50, respectively (Stevenson 2013) and there are indications of continued feasting and veneration of the graves into the early Roman period (Crease 2015, 51). 
funerary structures represent changes in the form of burial in the Roman period, ${ }^{34}$ but may also indicate a continuation of the social significance of the funerary ritual and monuments.

It became clear, however, at the beginning of our investigations that the vision of a villa-free hinterland around the civitas capital was itself an over-simplification. Significant sites of Roman-period settlement are indeed comparatively infrequent in the c. $10 \mathrm{~km}$ radius of rural areas surrounding Roman Canterbury, but those examples that have been recovered and recorded by the HER rarely make it into broader works and syntheses, making the apparent absence appear more stark. ${ }^{35}$ As our analysis of the area south of Canterbury has shown, this absence of well-known sites may be partly a product of the agro-pastoral nature of the area and the relative paucity of developmentand research-led archaeological inquiry. Work elsewhere in Kent-for example, on the Channel Tunnel Rail Link (HS1) at Westhawk Farm in Ashford and on Thanet- has demonstrated how much can be recovered in large-scale developer-funded excavations. ${ }^{36}$ Indeed one major infrastructure project in the Canterbury hinterland, the construction of the A2 Bridge by-pass in the 1970s, resulted in the identification of many new features in the area. ${ }^{37}$ Analysis by the project team of a range of evidence has brought to light the first villa likely to be associated with Canterbury, in Bourne Park, Bishopsbourne. ${ }^{38}$ The aisled hall and bathhouse at Wingham - which is, in any case, approximately equidistant to Richborough and nearer the Wantsum Channel than Canterbury - and the less convincing surface scatter of masonry at Blean (north of Canterbury) and the remains of walls at Swarling are the other contenders for high-status rural sites in the hinterland of Canterbury (Figure 1) ${ }^{39}$ In order to explore the social identities and interactions in the hinterland of Canterbury, we need a more complete view of the archaeological record. ${ }^{40}$ We also must avoid the generalizing social commentary which splits IA and Roman

34 For a survey of Canterbury's Roman period cemeteries, see Weekes 2011.

35 See, for example, the visual presentation of the Rural Settlement of Roman Britain project web GIS: http://archaeologydataservice.ac.uk/archives/view/romangl/ [last accessed 17 ${ }^{\text {th }}$ November 2018].

36 For the CTRL work, see Andrews et al. 2011a and 2011b; Booth et al. 2011; for Westhawk Farm, see Booth, Bingham and Lawrence 2008; for Thanet, see, for example, the east Kent access road work presented by Andrews et al. 2015a and 2015b.

37 See Macpherson-Grant 1980 for the A2 Bridge by-pass rescue investigations, although the evidence from the Roman period and later was never published.

38 For the Bourne Park 'villa', see Wallace et al. 2016.

39 For Wingham 'villa', see Dowker 1882; 1883; Jenkins 1984; Philp 2000. The CHP has been investigating the landscape setting of the bathhouse and aisled hall at Wingham, see footnote 30 . The complex is more likely to be related functionally and socially to Richborough and to military/imperial administration than to Canterbury. For Blean, see English Heritage 1999. For Swarling, see Philp 1960.

40 The wide variety of rural settlements excavated across Britain during development since 1990 has demonstrated that the traditional academic focus on 'villa' sites - more likely to be published than other types_-skews our understanding of rural Roman-period settlement, see Booth 2017, 56. 
Kent into, for example, east and west zones and be sensitive to local patterns within their broader context. ${ }^{41}$

\section{THE CANTERBURY HINTERLAND PROJECT}

The CHP is one of several recent projects which are focussing attention on the countryside and landscape in antiquity. The impressive results from the Rural Settlement of Roman Britain Project are derived primarily from compilation of data from excavations, while the English Landscapes and Identities Project worked with 'characterful' databases, such as site data from the Historic Environment Record. ${ }^{42}$ A key strength of the former is that it brings to light data previously available only through 'grey literature', while the latter examines changes across multiple periods. These projects, although combining large amounts of information for the first time and allowing for analyses of ancient rural Britain previously impossible, nevertheless leave gaps. ${ }^{43}$

Analysis on a large scale (e.g. 'the southeast') does not allow for individual features to be visible, resulting in site-type designations and symbols on a map, while the site scale does not show the landscape with which the inhabitants would have been familiar. The landscapes that people created gave meaning to, and derived much significance from, smaller site-scale features. Our compilation of data on a sub-regional scale benefits from both large- and small-scale investigations. The use of geophysics as a precursor to excavation or in areas with known features is common; ${ }^{44}$ the use of large-scale geophysics to investigate landscapes less so. The methodology here draws on the successes of other large-scale geophysical surveys - such as, in Britain, the Vale of Pickering survey ${ }^{45}$ which have demonstrated that geophysical prospection over large areas can serve to join and make sense of seemingly 'empty' areas between 'sites' identified through other means. ${ }^{46}$

Decontextualized, period-specific, broad-scale surveys are problematic, given that dots on the map from specific periods are commonly linked to each other, without awareness of the pathways, boundaries, and intervisibility between them. The division, for example, in some studies between settlement and funerary 'sites' can also be unhelpful; rigid

41 Such an east-west division is evident to an extent in the IA evidence and Romano-British pottery distributions. For the IA evidence, see Champion 2007; for the pottery distributions, see Pollard 1988, 197. 42 For the Rural Settlement of Roman Britain Project, see Allen et al. 2017; Smith et al. 2016, 2018; for EngLaId, see Gosden et al. 2012.

43 For example, sites known through aerial photograph, geophysics, antiquarian investigations, and surface material/metal-detection are not systematically included in Smith et al. 2016.

44 For geophysics in urban and extra-urban areas, see Creighton 2016 (Silchester); Johnson 2013a and 2013b (Ammaia, Portugal); Guest and Young 2010, Young 2012 (Caerleon).

45 For the Vale of Pickering survey, see Powlesland 2003, the Landscape Research Centre website http:// www.landscaperesearchcentre.org/index.html [last accessed $8^{\text {th }}$ October 2017] and Breeze 2014 (together with other rural projects using geophysical analysis).

46 See Campana 2015 for 'empty spaces'; Morrison, Thomas and Gosden 2014 for 'blank spots'. 
categorization and narrow focus prevent integrated views of complex material. Bourne Park, with its apparent mixture of funerary and settlement features and overlapping material from the Bronze Age through to the early Medieval period, ${ }^{47}$ is a particularly good example of where site-type rigidity and narrow chronological focus would be misleading; to call it simply a 'Roman villa site', for example, would underplay the complexity of the archaeological realities. Indeed, in the context of the current discussion, it is not clear that the term 'site', with its implicit notion of a bounded area of activity, is valid at all.

The CHP has, therefore, been conducted on a multi-period, sub-regional scale, putting a combination of evidence into a wider context and considering the physical and symbolic relationships between 'places' and features. We have employed a mixture of targeted large-scale geophysical and topographical analysis, comprehensive investigation of available aerial photographs, satellite, and LiDAR imagery, metal-detected finds, and synthesis of results of antiquarian, commercial, and academic excavation. ${ }^{48}$ Each technique employed provides different information for a more complete understanding of the landscape and a balance between scale and resolution has been struck through full aerial photographic coverage of the whole of east Kent and areas targeted for more intensive investigations..$^{49}$ Examining connections to, and incorporation of, natural features and topography in how people moved through and perceived the landscape as they made choices and changes complements the study of the morphology of archaeological remains. This article focusses on the largest survey area at Bourne Park, Bishopsbourne (Figure 2), and includes results from investigations of the surrounding landscape, drawing also on our other surveys at Patrixbourne and Goodnestone (Figure 1).

\section{PREVIOUS WORK IN BOURNE PARK}

Bourne Park is an area of c. 70ha of relatively open parkland between the villages of Bridge to the north and Bishopsbourne to the south, five kilometres to the southeast of Canterbury (Figure 1). As is common across east Kent, there are a large number of barrow mounds or tumuli in Bourne Park, particularly of early Medieval date. More than 100 tumuli were visible in the Park area in 1771 (some of which were excavated

47 Bourne Park also contains several Medieval and post-Medieval features, but the present article is limited to earlier periods.

48 The CHP was set up in 2013, following promising small-scale investigations in Kent in 2011-2012, see Wallace et al. 2014 and 2016.

49 The aerial photographic analysis for Kent has largely been undertaken for the project by Chris Blair-Myers, whose results significantly advance the Royal Commission on the Historical Monuments of England study, conducted in the late 1980s (RCHME 1989). Kent was a 'pilot' study for the RCHME and the main aim was to produce a classification system to be employed in the Monuments Protection Programme. The techniques used in Kent were subsequently developed in later UK National Mapping Programme projects, but the Kent material was never revised. 
by prolific barrow-digger Bryan Faussett), ${ }^{50}$ but have since been ploughed down. Lord Albert Conyngham, the one-time tenant of Bourne Park House and first President of the British Archaeological Association, excavated at least three early Medieval barrows in the Park in 1844. ${ }^{51}$ The tenant Matthew Bell found a number of Roman-period and early Medieval burials when he excavated, and later dredged, the artificial lake in the Park in 1846 and $1898 .{ }^{52}$ The Park also attracted the attention of a nineteenth-century vicar, Francis Vine, as, in his view, a site of Caesarean campaigning. ${ }^{53}$ Vine's observations of excavations, cropmarks and earthworks have proved a valuable source of information, even if his interpretations are somewhat optimistic. Vine himself excavated three Roman burial mounds at Gorsley Wood (Figure 2), southwest of Bourne Park, in 1882 or $1883 .{ }^{54}$ These were inhumations in stone-lined cists covered by (probably conical) burial mounds without surrounding ring ditches. They measure c. $9-12 \mathrm{~m}$ in diameter (which makes them 'large' according to Struck $)^{55}$ and are enclosed by an earthen bank. Roman barrows are features of elite burial and several are known around Canterbury, although they are nowhere near as numerous as the Bronze Age and early Medieval examples. ${ }^{56}$

During the construction of a housing development in 1961, near the crest of Bridge Hill east of Bridge Hill road (i.e. outside Bourne Park), M. B. Watson excavated two large pits and an occupation area dating to the LPRIA ('Iron Age rubbish pits' on Figure 3). ${ }^{57}$ Approximately $300 \mathrm{~m}$ southwest of this excavation on Bridge Hill within Bourne Park, from 2003 to 2006, Paul Wilkinson led a Kent Archaeological Field School excavation

50 See Faussett 1856. A full description of antiquarian activities in Bourne Park is not possible here, but locations of relevant features (where known) are noted on Figure 2. For round-barrows in east Kent, see Ashbee and Dunning 1960. For discussion of the early Medieval examples, see Meaney 1964; Smith 1908; Webster and Cherry 1974.

51 See Conyngham and Akerman 1844, Wright 1845.

52 See Bell 1848 and 1880-1902.

53 Through careful examination of the topography and reference to Caesar's de Bello Gallico, Vine (1886) drew up possible battle lines between 'Briton' and 'Roman' in and around the Park and posited an indigenous oppidum in the area of the Park known as 'Old England's Hole'(a probable chalk quarry currently represented by a large depression). Conyngham excavated a tumulus near 'Old England's Hole' containing an inhumation burial of possible Roman or early Medieval date which included a 'breastplate of silver, pierced as by a spear, a curved sword six inches out of line, two bronze shoulder-pieces, four spear-heads, and a wooden vessel banded with bronze bands' (Vine 1886, 173). An Early Medieval date is more likely given the description, but these objects have not been located. Haselgrove and Fitzpatrick are undertaking a project, In the Footsteps of Caesar: the archaeology of the first Roman invasions of Britain, which aims to reassess the impact of the Caesarian invasions (inspired in part by the discovery of a Roman helmet from a mid-first century BC burial near Bourne Park): https://www2.le.ac.uk/departments/archaeology/research/ projects/footsteps-of-caesar [last accessed $7^{\text {th }}$ November 2017]. Our own work is not motivated by a mission to prove or disprove Caesar's commentary on his experiences in Kent, but the historical sources are one element to consider, with caution, as we try to understand the social landscape.

54 For the burials in Gorsley Wood, see Vine 1882; Vine 1883.

55 Struck 2000, 89, fig. 9.3.

56 See Weekes 2011. For high-status burial in Roman Britain, see Struck 2000.

57 For the 1961 excavation, see Watson 1963. 

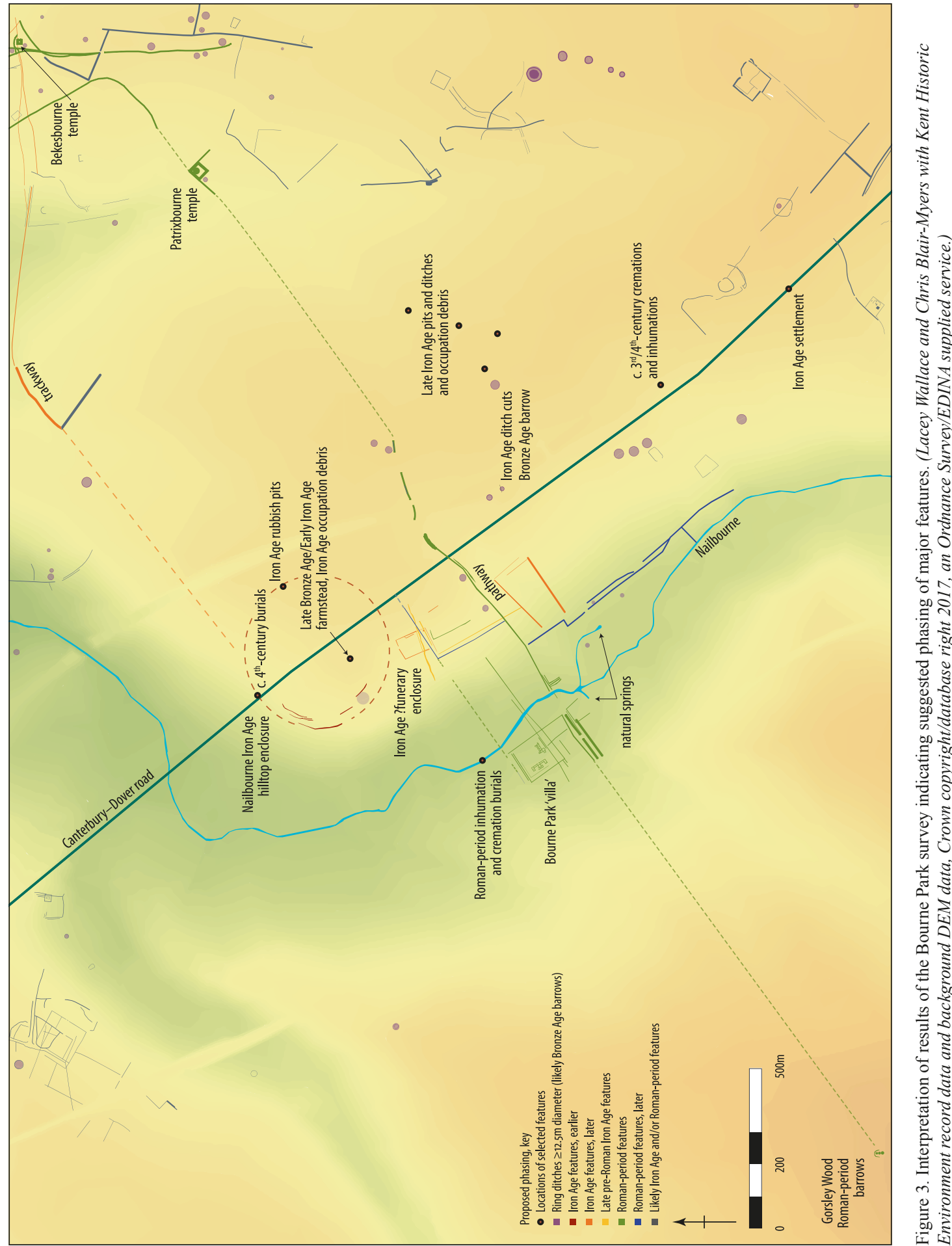
of a multi-period site. ${ }^{58}$ Features within this excavation dated from the late Neolithic/ early Bronze Age through to late post-Medieval (including a large number of early Medieval burials), but of most direct relevance here is the 'farmstead' within an enclosure ditch, represented by an area of pits, postholes, and ditches dating to c. 750-550 BC ('Late Bronze Age/Early Iron Age farmstead, Iron Age occupation debris' on Figure 3). Together, these excavations suggest two phases of occupation, perhaps with shifts in the geographical focus of activity in different periods. The LPRIA pit assemblages may represent structured deposits - they contained pottery, animal bone (ox, sheep/goat, and pig), charred wood, a spindle whorl, fragments of copper-alloy, and a copper-alloy bead-possibly related to a ritual deposition.

IA activity in the wider area is also apparent from the coin finds from Bridge and Bishopsbourne and suggests far-reaching social networks in the first century BC. An IA silver coin was found in the Park and other IA coins are known from the Bishopsbourne and Bridge area, including six IA copper-alloy coins of the Cantii, one of the Atrebates, two Thurrock-type potins of the late second/early first century BC, a struck gold quarter stater of the Morini dating to c.75-60 BC, an imported Gaulish cast bronze potin dated to c. $100-50 \mathrm{BC}$, a stater of the Durotriges dating to the second half of the first century $\mathrm{BC}$ and an IA silver coin of Cunobelin from Bridge. ${ }^{59}$

\section{CANTERBURY HINTERLAND PROJECT WORK IN BOURNE PARK}

In addition to the ongoing county-wide analysis of aerial photographs, LiDAR, and antiquarian and modern excavations, the first phase of the CHP focused on Bourne Park. Bourne Park is private land with public access, currently in active pasturage, the location of a scheduled monument (early Medieval cemetery, NHLE 465133), and not under threat from development, agriculture, or environmental factors. The Park lies on the chalk downs, with alluvial clay and flints in the river valley and exposed chalk on the ridges. The Roman-period Dover-Canterbury road, and probably an earlier trackway ('ridge route'), ran along the ridge to the north-east of the Park and is now mostly overlain by Bridge Hill road (former A2).

The Bourne Park survey comprised magnetic gradiometry (readings taken every $0.25 \mathrm{~m}$ along $0.5 \mathrm{~m}$ traverses in $30 \times 30 \mathrm{~m}$ grids with a Bartington $601-2$ fluxgate gradiometer) over c. 60 ha, electrical resistance (readings taken every $0.5 \mathrm{~m}$ along $0.5 \mathrm{~m}$ traverses in $30 \times 30 \mathrm{~m}$ grids with a Geoscan Research RM15-D resistance meter in parallel twin-probe configuration over an area measuring 1ha), ground-penetrating radar (GPR; undertaken by Lieven Verdonck using a Sensors \& Software Spidar network at 500MHz frequency, of several channels, mounted in parallel onto a wooden frame and towed behind

58 See Wilkinson 2008; Wilkinson and Macpherson-Grant 2014.

59 Coin of Atrebates (CCI 950154); potins (PAS KENT-BEFA55, KENT-0BDD22); stater (PAS KENT134AD2); Gaulish potin (PAS KENT-01D293); Durotriges stater (PAS KENT-0BC156); Cunobelin coin (CCI 950166). Nash 1979 discusses the two potins from Middle Pett Farm, Bridge. See Holman 2000 for a survey of Kentish IA coinage. 
an all-terrain vehicle with a transect spacing of $0.125 \mathrm{~m}$ and measurements taken every $0.05 \mathrm{~m}$ over an area measuring $1.7 \mathrm{ha}$ ), and a full micro-topographic survey, ${ }^{60}$ plus detailed investigation of past excavations, aerial photography, and metal-detected finds. Some of the metal-detected finds collected in the 1980s and 1990s from Bourne Park have been examined, but the majority of these are known only from an archived list as they were most likely sold. Additionally, two small trenches were excavated in 2016 in collaboration with Steve Willis of the University of Kent. The initial results on the character of the buildings investigated are included here. Other CHP surveys drawn on in this article are the magnetic gradiometry survey (2017) within a large arable field at Goodnestone (a site of prior intensive metal-detecting and surface collection) and the magnetic gradiometry and GPR survey (2014) within a private garden at Patrixbourne (see survey areas on Figure 1 and Figure 2).

Combined results are simplified for presentation in Figure 2. A detailed description of the Bourne Park survey up to 2014 has been published and need not be repeated here, but the main features that constitute the basis for the interpretations here are shown in schematic form in Figure 3. A palimpsest of features has been revealed and phasing of the features shows a variety of changes over time. Little has been excavated, so the phasing is largely based on alignments, morphology, relationships, similarity to excavated features, and the relative chronologies evident in intercutting/abutting relationships of the cropmarks and geophysical anomalies. Key features are briefly described in the following sections: the Roman-period road, ridge route, and stream valley; the major trackway and paths; the large enclosures; significant concentrations of settlement; temples; and the barrow mounds and other burials.

\section{THE VALLEY, RIDGE ROUTE AND ROMAN ROAD}

North of Bourne Park lies the intersection of the Nailbourne stream valley with the Roman-period road and the hypothesised pre-Roman ridge route between Dover and Canterbury. Today, water is not always present in the stream and it can be crossed in times of drought. Bishopsbourne, named Burnes in the Domesday Book, was held directly (in demesne) by the Archbishop of Canterbury and was of comparable size to the royal estate at Faversham and larger than that at Eastry. ${ }^{61}$ Burnes contained two mills, indicating that the flow of water must have been more reliable and copious in the past. Two springs within the Park provide the immediate source of the water; springs are relatively rare in the area with the nearest being c. $4 \mathrm{~km}$ upstream and no others within the area of Figure 2. The source of the Nailbourne lies at Lyminge and the stream continues as the Lesser or Little Stour to the Wantsum Channel (Figure 1).

The line of the Roman-period Canterbury-Dover road is relatively well known and is partially visible as cropmarks, where it deviates around a probable Bronze Age barrow

60 See Wallace et al. 2014 for a discussion of the survey techniques and Wallace et al. 2016 for overview of geophysical survey up to 2014. For further details of the GPR, see Verdonck 2016.

61 Christopher Loveluck pers. comm.; Lawson and Killingray 2004, 63. 

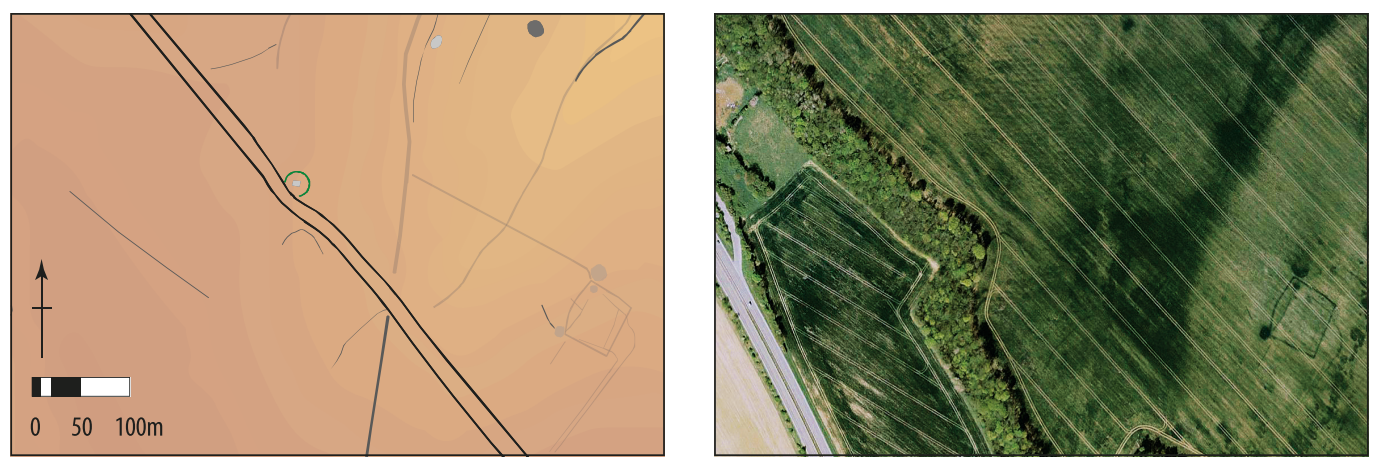

Figure 4. Detail of Canterbury-Dover road deviating around probable Bronze Age barrow. (Lacey Wallace and Chris Blair-Myers; including DEM data (Crown copyright/database right 2017, an Ordnance Survey/EDINA supplied service) and 2007 Google Earth satellite image (C) 2018 Infoterra Ltd. and Bluesky).)

(Figure 2 and Figure 4). Elsewhere, it has been excavated during road and utility works along the line of the modern road (the Old Dover Road/Bridge Hill/A2), which overlies some of it. ${ }^{62}$ Precisely when the road was provided with a metalled surface and roadside ditches is not entirely clear, and may have differed along the route, but is likely to have been in the late first or early second century AD.

\section{MAJOR TRACKWAY}

A significant trackway is a dominant feature in the area of Figure 2, appearing in cropmarks at times as a single ditch and elsewhere as parallel ditches defining a path. In the magnetic gradiometry results from the Goodnestone survey area, its character as a ditch-lined path or trackway is clear. The nature of cropmarks means that the trackway is identifiable only intermittently, but it would appear to continue for several kilometres, curving towards the ridge route/road at both ends (Figure 2). While the locations where the trackway meets the road are hypothetical extensions from the nearest visible sections, it seems that the northern end met the road just south of the Nailbourne crossing and the southern end perhaps at the location where the Canterbury-Dover road turns slightly to descend into the valley towards Dover. It appears to link the Nailbourne hilltop enclosure (described below) to the probable IA-Roman-period nucleated settlement/ temple/sanctuary site at Goodnestone (described below), then turns south to rejoin the ridge route before the road enters the Dour valley.

Sites of interest associated with this trackway provide further evidence of its significance in connecting meaningful places and facilitating communal activities (Figure 2; see also below). Its importance can also be seen in the distribution of both IA- and Romanperiod Portable Antiquity Scheme finds which cluster along the ridge route and trackway (Figure 5). This trackway respects a number of Bronze Age barrows (and therefore seems to post-date them) and appears to connect four probable IA enclosures and the major IA/Roman-period nucleated settlement at Goodnestone, indicating that it is probably of

62 See Tatton-Brown 2001 for the line of 'Watling Street' in Kent. 

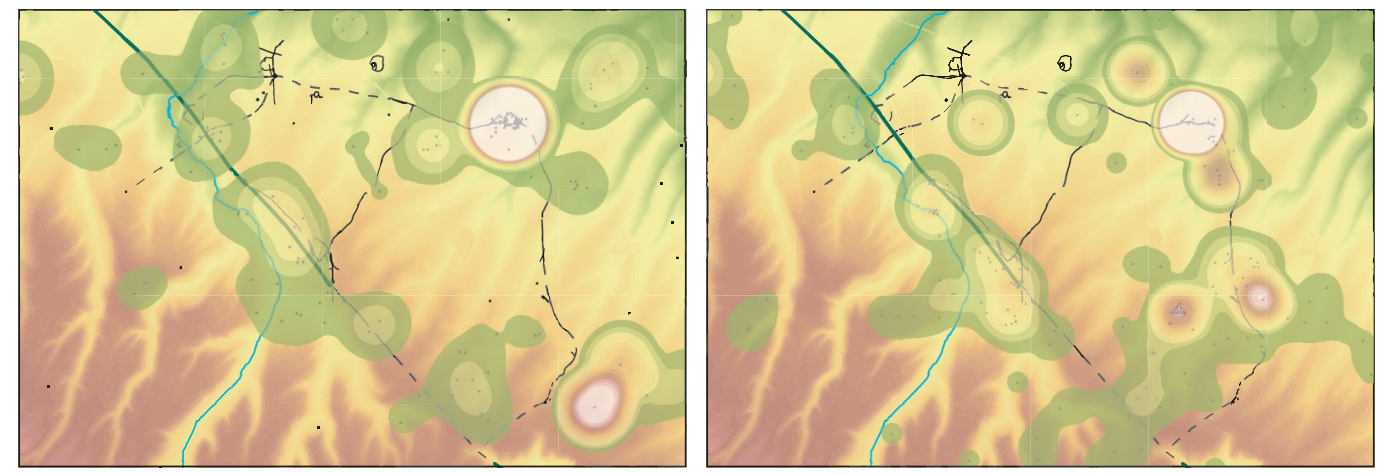

Figure 5. Area of Figure 2 showing a kernel density plot of Iron Age (left) and Roman-period (right) Portable Antiquities Scheme finds (accessed 21 $1^{\text {st }}$ March 2017), highlighting the significance of the trackway. (Lacey Wallace and Chris BlairMyers with Kent Historic Environment record data and background DEM data, Crown copyright/database right 2017, an Ordnance Survey/EDINA supplied service.)

broadly IA date. At the Bekesbourne Romano-Celtic temple (discussed below), there appear to be two phases of the trackway, one of which crosses the temple building, indicating that the trackway was possibly altered in preparation for, or shortly after, the construction of the temple.

The half of the trackway nearer to Bourne Park and Canterbury is connected back to and across the ridge route via at least one, and possibly two, 'paths', each apparently defined by single ditches or surfaces (Figure 2). The first path begins along the trackway approximately mid-way between the Bekesbourne temple and the Goodnestone nucleated settlement and continues south/southwest to intersect with another path that runs along the ridge and with the Barham temple (described below). The second, more northerly of these two paths begins closer to Canterbury, to the north of the trackway, at one of the probable IA large sub-circular enclosures (described below), where it has the character of a ditch-lined road. It crosses the trackway at the location of the large Bronze Age barrows and the Romano-Celtic temple at Bekesbourne (described below). One branch continues south (for only a short distance before, in our evidence at least, it is lost) and the other branch continues further, initially as a discontinuous feature in our evidence, to the southwest past the temple at Patrixbourne (described below), and (although only intermittently visible in the aerial photographs) then as a strong linear feature through the gradiometry survey area in Bourne Park. Where the path is most clear in the Park, it runs alongside two large Bronze Age barrows and across the valley between the "villa'-type structural complex (described below) and the natural springs (Figure 3). It has been shown in Figures 2 and 3 to continue south and west because of its neat alignment to the Roman-period barrows in Gorsley Wood (described above). The major trackway and both paths appear to form significant routes across the landscape that allowed people to reach places of worship, reverence, and burial.

Within Bourne Park, this path is crossed by one of the first phase of field boundaries/ enclosures but abutted by a boundary of its second phase (Figure 3), and therefore 
post-dates the first phase of enclosure and the (probably funerary) rectilinear enclosure (described below). It is possible that a 'large probably IA/Belgic enclosure ditch' excavated under rescue conditions during construction of the modern A2 Bridge bypass in 1974 could represent drainage or demarcation of this feature (i.e. a portion of this 'path'), although the conditions of excavation and imprecision of the published plan make it difficult to correlate precisely. ${ }^{63}$ As the path may link Roman-period burial mounds at Gorsley Wood to the temples at Patrixbourne and Bekesbourne, and because it was constructed in alignment with the valley enclosures and perpendicular to the Roman road, it is likely of Roman date. The path may have been used for burial processions at the burial mounds and religious rituals enacted at the temples at its northeastern end.

\section{LARGE ENCLOSURES}

Three large and one smaller sub-circular ditched enclosures lie near to the trackway and appear to be directly related (which came first, trackway or enclosures, is unclear) to the route it takes from the Nailbourne/ridge to the nucleated settlement at Goodnestone (Figure 2). Beginning where the trackway appears to meet the ridge route just south of the Nailbourne stream, geophysical survey and aerial photographs indicate the partial remains of a c. 9ha curvilinear multi-ditched hilltop enclosure ('Nailbourne Iron Age enclosure' on Figure 3) close to the Nailbourne. This enclosure consists of fragments of concentric sub-circular ditches near the crest of the hill defining its western side; extrapolating in an approximate circle, the enclosure would extend across the ridge and road, and, therefore, probably pre-dates the road. These ditches have not been dated through excavation, but a multi-ditched hilltop enclosure of this size is most similar to IA examples. Finds from the two excavations discussed above, which probably fall within the area of the enclosure, suggest possible use in the Early, Middle and LPRIA ${ }^{64}$ A possible Bronze Age barrow, now represented by a c. $35 \mathrm{~m}$ diameter ring of dipolar anomalies, also lay within the area of this enclosure (Figure 3).

Following the trackway c. $2 \mathrm{~km}$ northeast, a second c. 6.7 ha irregular enclosure (at TR 203 550) lies to its north. The ditch-lined path (described above) runs alongside this enclosure and south to the Bekesbourne temple with another possible branch running southwest to meet up with the major path within the Bourne Park survey area. One kilometre east, south of the trackway, lies a sub-circular enclosure (c. $95 \times 120 \mathrm{~m})$ with two ditch-lined entrance paths leading to breaks within its enclosure ditch. One kilometre further east down the trackway and c. $600 \mathrm{~m}$ to its north, lies the remains of a complex irregular enclosure (at TR 229 548) represented by remarkably clear ditches. It measures c. 8ha and contains two smaller enclosures, the smallest of which is sub-circular. While none of these enclosures has been investigated with excavation or survey, their sizes and shapes are consistent with middle-to-late IA enclosures.

63 Macpherson-Grant 1980, 151, 152, fig. 13, no. 4.

64 See Wilkinson and Macpherson-Grant 2014 and Watson 1963. 
To the south of the Nailbourne hilltop enclosure lies a rectilinear enclosure (Figure 3) identified in geophysical results with straight (but not equal) sides, sharp corners and two entrances (on the northern and western sides). This enclosure was larger in an earlier phase (c. $67 \times 100 \mathrm{~m})$ and contains in the southeastern corner a c. $7 \mathrm{~m}$-diameter anomaly. In a second phase, the enclosure was reduced in size (c. $67 \times 60-71 \mathrm{~m})$ and a substantial ditch/terrace constructed parallel to it, to the south. The enclosure is at a c. $70^{\circ}$ angle to the Roman road, suggesting it may pre-date it. In Kent, rectilinear enclosures can be Bronze Age, IA, or Roman-period, settlement or funerary. While sub-rectangular enclosures of this approximate size are known from the Bronze Age (e.g. the beaker-period enclosure at Minster-in-Thanet, c. $80 \times 40 \mathrm{~m})^{65}$ and Late Bronze Age activity was noted in nearby excavation, ${ }^{66}$ the sharp corners of this enclosure appear to be more similar to IA and Roman-period examples. The relatively small area indicates that it was perhaps a farmstead or funerary enclosure - internal features form no obvious structural patternsbut, the chalk is close to the surface on this steeply sloped hillside, while the stream, springs, alluvium, and relatively flat site in the valley bottom would be more conducive to occupation and cultivation, perhaps supporting a mortuary function. Additionally, the strong parallel ditch/terrace to its south suggests a monumentalization that is not characteristic of IA farmstead enclosures. While larger than most ditched mortuary enclosures of the IA in Britain, this enclosure can be compared to other large funerary enclosures on the Continent (e.g. Acy-Romance 'La Croizette' c. 80 x 21m). ${ }^{67}$ Its unequal sides and lack of alignment and orientation to the Roman road make a Roman-period ditched or walled cemetery unlikely. ${ }^{68}$ The large anomaly in the southeastern corner could represent a pit, pyre feature, or burial vault.

\section{SETTLEMENT}

IA and Roman-period occupation is known in the area from surface finds and smallscale or rescue excavations, many along the ridge route and discovered during modern roadworks and construction along/near the modern A2 (Figure 2). At the approximate midway point along the length of the trackway, a dense area of enclosures has been revealed through the CHP 2017 gradiometry survey at Goodnestone. A large number of metal-detected and surface finds have been recovered over the last thirty years at this site, including nearly 300 IA coins, an exceptionally high density. For comparison, there are c. 2,577 IA coins catalogued by the Portable Antiquities Scheme (which includes the Celtic Coin Index) from the whole of the area covered in Figure 1, making those from this single field more than $10 \%$ of that total. The character of the assemblage of other

65 For the Laundry Road enclosure, Minster-in-Thanet, see Boast and Gibson 2000.

66 Wilkinson 2008.

67 For Acy-Romance, Ardennes, see Lambot, Delestrée and Méniel 1993.

68 Roman-period walled cemeteries in Kent can be found at Lockham Wood, Boughton Monchelsea (TQ

75 SE 2, c. $23 \times 26 \mathrm{~m}$ ), at Barming (TQ 75 SW 23, c. $27.4 \times 9.1 \mathrm{~m}$ ), and at Tilmanstone (known from cropmarks) (TR 35 SW 376, c. 25 x 25m). Larger ones can be found at Plaxtol, Kent, (91m square and contains a barrow in one corner), at Springhead, Kent, (c. $120 \times 120 \mathrm{~m}$ ) and elsewhere in the south-east at St Albans, Hertfordshire, (Folly Lane Ceremonial enclosure, c. 120 x 170m). 


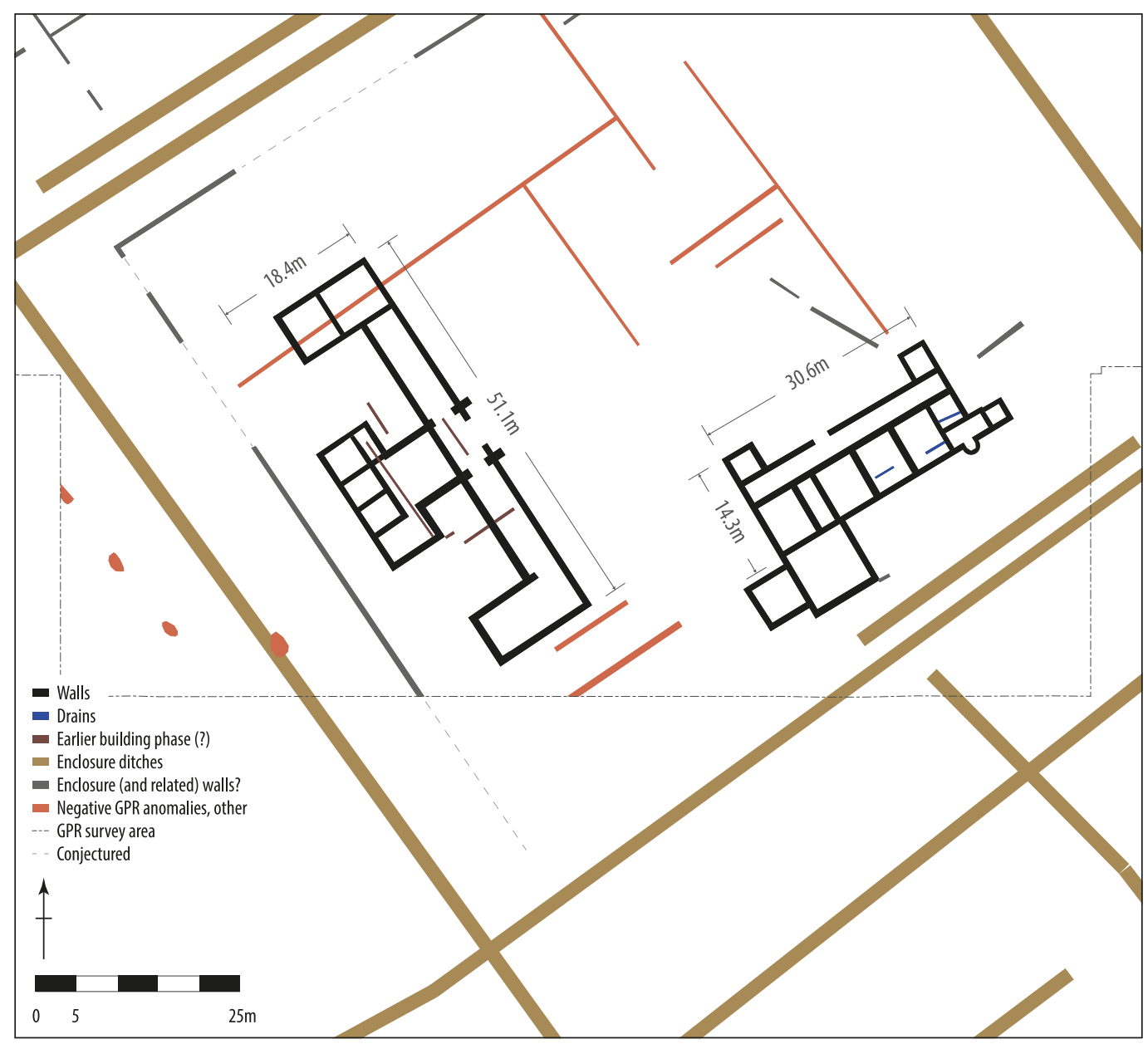

Figure 6. Schematic and simplified interpretation of the GPR and gradiometry survey results of the Bourne Park high-status structural complex. (Lacey Wallace and Lieven Verdonck.)

metal-detected finds there (e.g. c. 2,900 Roman coins spanning from the mid-first-century to the late fourth-century, adornment, military objects, pottery etc.) indicate a possible temple or sanctuary site with origins in the LPRIA. ${ }^{69}$ Geophysical survey revealed a complex nucleated rural settlement of enclosures separated by pathways leading to an open space, while a rectilinear feature in the field to the east visible in aerial photographs is thought to be an ancient masonry building by those who plough the land. ${ }^{70}$

Within the Bourne Park survey area, a high-status structural complex lay in the valley bottom which is visible as anomalies in aerial photographs, magnetic gradiometry,

69 Analysis of surface finds is currently underway, but partial reports on certain objects exist: see Bishop 1995; Holman 1998; Mackreth 1997; Still 1997. For the coins, see Holman 2005, 21-23.

70 Further CHP survey is planned at this site. 
electrical resistance, and GPR. One large, possibly walled, enclosure and several smaller enclosures lie perpendicular to the Roman road on the southwestern side of the stream and metal-detected coins and limited excavation confirm habitation in the valley bottom enclosures in the later Roman period at least. Within the largest enclosure are two buildings: the southern of these is a typical 'winged-corridor' building with a façade measuring c. $30.6 \mathrm{~m}$, while the western structure is of an unfamiliar form with a long 'room' along a frontage measuring c. $51.1 \mathrm{~m}$, two wings projecting back from each end, and a T-shaped wing at the rear of the centre (Figure 6). The western structure has an uncommon ground plan for which we have yet to find a close parallel, although the Winterton villa in Lincolnshire is similar. ${ }^{71}$ Its wide façade suggests that it may have served to communicate wealth and status to those viewing it from the road. The structures had walls of rough flint and evidence of some architectural pretension in the form of ceramic-tiled roofs, at least one hypocaust room in the winged corridor building, painted wall plaster, and possible window glass. The 'winged-corridor' building appears Romano-British in character and can be compared to many similar row-type buildings with a corridor and pavilions added; this structure is perhaps most similar to Mansfield Woodhouse in Nottinghamshire. ${ }^{72}$

Although only full-scale excavation would allow us to test whether this complex follows a common pattern whereby Roman-period buildings, first in timber and later in masonry, follow occupation on a LPRIA site, the GPR results indicate that at least one earlier rectilinear structure preceded the western structure. A possible third building (visible as an area of high electrical resistance with some linear features in the GPR results) could be a processing/storage building, similar to those on other 'villa' sites in southeastern Britain. ${ }^{73}$

\section{TEMPLES}

The Bekesbourne Romano-Celtic temple (Figure 3 and Figure 7) is located on the south side of the major trackway (which seems to have been re-routed after the temple was constructed to curve around it) at the intersection of one of the paths in an area of probable Bronze Age (and, later, early Medieval) barrows. It is aligned approximately east-west with an entrance on the eastern side. The available evidence appears to show only the temple building, which was perhaps of the type that we find, for example, in Kent at Worth, a nearly-square roofed structure comprising an outer wall of chalk blocks and smaller internal cella, or at Lullingstone, where the later phase of the 'temple

\footnotetext{
71 See Stead 1976.

72 See Rooke 1787. The winged-corridor building is part of a widespread tradition in northern Gaul and southern Britain and the structure may have been built in the second century, when it becomes common in southeastern Britain, see Taylor 2011, 181-182; Smith et al. 2016, 112. Analysis of the GPR evidence suggested the later addition of the apsidal structure into the southeastern corner and this has been confirmed through excavation.

73 Note the aisled halls, barns, etc. at e.g. Lullingstone, Horton Kirby, Hog Brook, see Taylor 2011, 186-189; Smith et al. 2016, especially chapters 3 and 4.
} 

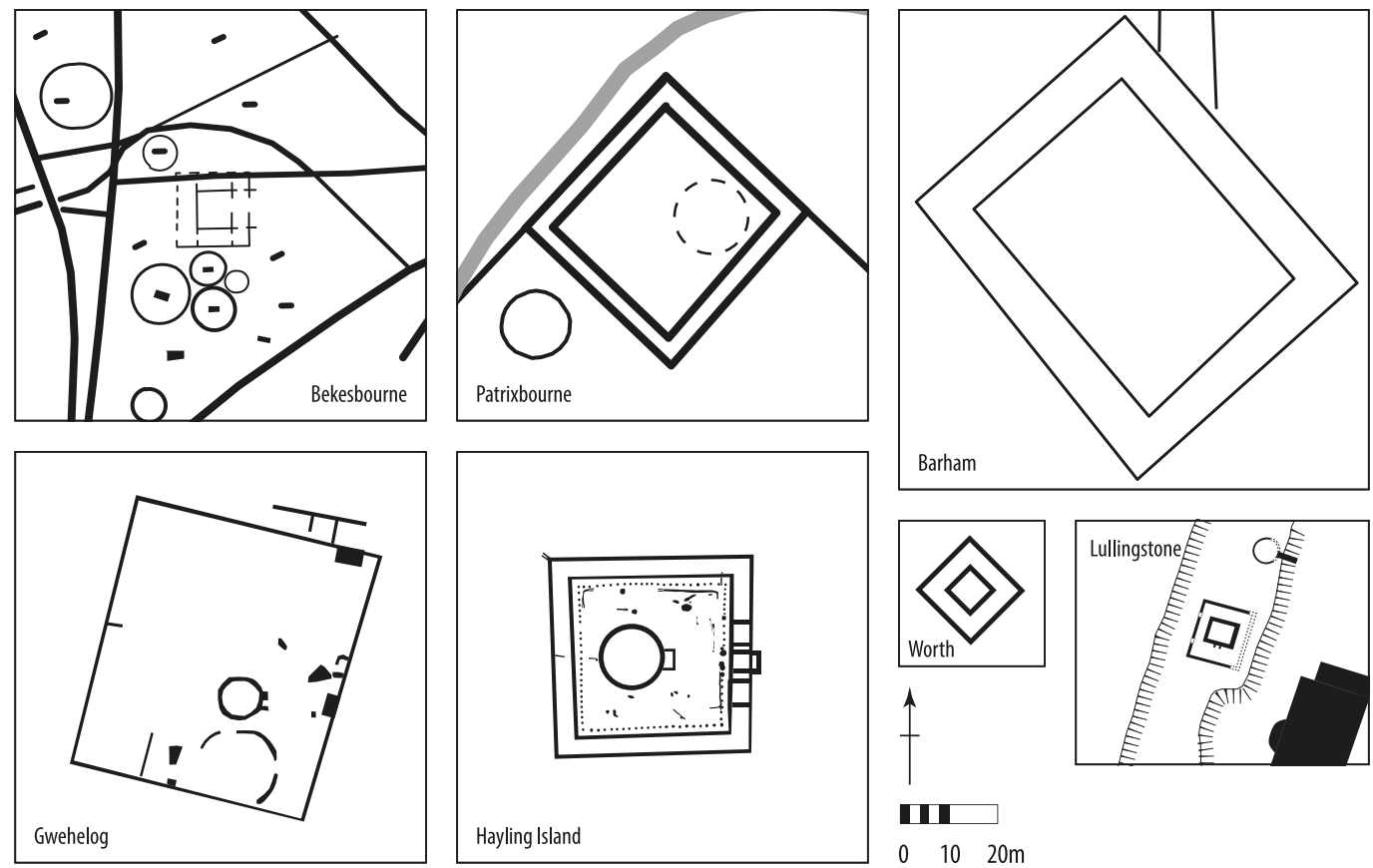

Figure 7. Interpretations of possible temples at Bekesbourne (likely cella, cf. Lullingstone), Patrixbourne (possible portico or ambulatory and internal structures, cf. Hayling Island), and Barham (similar morphology to Patrixbourne, but nothing known of internal structures). Temples at Gwehelog (after Wilson 1990), Hayling Island (after King and Soffe 1991), Worth (after Klein 1928), and the temple-mausoleum at Lullingstone (after Meates 1979) shown to aid comparison. Scale 1:2,000. (Lacey Wallace and Chris Blair-Myers.)

mausoleum' consisted of an inner cella surrounded on all sides by an open veranda supported by pillars/columns. ${ }^{74}$ The outer 'wall' at Bekesbourne measures c. $15 \times 15 \mathrm{~m}$ and the cella is c. $8 \times 7 \mathrm{~m}$. This structure is currently known only from aerial photographs and satellite imagery.

Approximately $700 \mathrm{~m}$ to the southwest of the Bekesbourne temple lies the probable temple at Patrixbourne (Figure 3 and Figure 7), which is on the same alignment as the road. ${ }^{75}$ Intermittent stretches of ditch may link these two and the path that appears to reach the Gorsley Wood barrows could be the same curvilinear feature that runs alongside the northwest of this enclosure. Aerial photographs, magnetic gradiometry and GPR at Patrixbourne revealed a double rectilinear enclosure aligned northwest to southeast measuring c. $43 \times 41 \mathrm{~m}$ with an arrangement of pits or postholes in the northeastern internal quadrant indicating a possible round structure c. $15 \mathrm{~m}$ in diameter, perhaps a cella. No entrance is visible, but the northeastern side had been damaged by a modern storage tank. Given the size of the double rectilinear feature, it can probably be compared to the

74 For Lullingstone, see Meates 1979; for Worth, see Klein 1928.

75 The results have not yet been published, please contact the authors for further information. 
temple portico at Hayling Island, rather than representing the 'Romano-Celtic' temple type identified at Bekesbourne. It is unclear from the GPR whether the feature represents ditches, masonry walls (as at Hayling Island) or timber structures.

The second, more definite, path linking the trackway to the ridge route/road leads to the enclosure of the possible temple at Barham, which was partially excavated during the construction of the A2 Bypass, although it has never been fully published. ${ }^{76} \mathrm{As}$ at Patrixbourne, a large double-rectilinear enclosure (outside measurements c. $72 \times 60 \mathrm{~m}$; interior c. $55 \times 41 \mathrm{~m}$ ) there may again represent the edge of a 'temenos' within c. $20 \mathrm{~m}$ of, and also aligned to, the northern side of the Canterbury-Dover road, with a cella (not identified) within. Stukeley described three barrows (one larger and two smaller) enclosed in a double square entrenchment near this location, possibly indicating the re-use of this enclosure for early medieval burial mounds. ${ }^{77}$

Enclosures surrounding temple buildings are common in LPRIA and Roman Britain, sometimes masonry built. The double-rectilinear enclosure is less common, however, and parallels for such features are usually sought in a band across central Gaul. The boundary portico of the Hayling Island 'Gallo-Roman' temple provides the closest parallel in Britain for the features at Patrixbourne and Barham. ${ }^{78}$ But other large double-ditched/portico enclosures known elsewhere in Britain at, e.g., Gosbecks (measuring c. 100x100m), Gwehelog (c. 50x56m) ${ }^{79}$ and Hailey Wood Camp (c. 70x60m), may fit into this group.$^{80}$ Double rectilinear features, if of significant size, may need to be considered of 'Hayling Island type' rather than large examples of the more common British 'Romano-Celtic' type. It is risky, in the absence of more secure evidence for these temples, to be firm in making precise links to comparanda in Britain and Gaul.

\section{BURIALS AND BARROWS}

Large ring ditches which may represent Bronze Age round barrows are plentiful in this area, as across most of east Kent. ${ }^{81}$ Analysis of aerial photographs and excavations has identified c. 2400 ring ditches in the area of Figure 1, c. 1300 of which measure more than $12.5 \mathrm{~m}$ in diameter and probably date to the Bronze Age - the remainder are more likely early Medieval (Roman-period barrows often lack a surrounding ring ditch, as at

76 It is illustrated, however, in Macpherson-Grant 1980.

77 Stukeley 1776.

78 For Hayling Island and continental comparanda, see King and Soffe 1991.

79 For Gwehelog, see Wilson 1990, 16.

80 For Hailey Wood Camp, see Moore 2001

81 Probable Bronze Age barrows (here represented by excavated barrows and ring ditches over $12.5 \mathrm{~m}$, i.e. those most likely to be Bronze Age barrows rather than roundhouses or barrows of Roman or early Medieval date) have been recorded throughout east Kent in the CHP's aerial photographic and LiDAR analysis, although they are particularly dense east of Canterbury. In this more dense area, there are c. 1260 Bronze Age barrows in a c. $500 \mathrm{~km}^{2}$ area, averaging about 2.5 per square kilometre, a very high density considering the surface area of villages, roads, woods, and other areas where cropmarks do not appear. For funerary practices in the broader Transmanche region, see Hammond 2010. 
Gorsley Wood). Within the area of Figure 2 lie slightly fewer than 600 probably Bronze Age ring ditches greater than $12.5 \mathrm{~m}$ in diameter and slightly fewer than 200 smaller, probably early Medieval, examples; within the area of Figure 3, the 46 supposed Bronze Age ring ditches are illustrated. The impact of one of these barrows on the line of the Roman-period road has already been noted - the road deviated around the barrow as illustrated in Figure 2 and Figure 4. Elsewhere, the location of the Bekesbourne temple appears to be related to the large Bronze Age barrows and the path leading across the valley in Bourne Park has been positioned to run alongside other large barrows.

Burials of IA and Roman date cluster along the ridge route and in the valley. Only one certain IA burial is known - that of the Bridge helmet burial. ${ }^{82}$ Roman-period burials have been identified only along the road, ${ }^{83}$ in the valley near to the high-status structural complex, ${ }^{84}$ and monumentalized as burial mounds across the valley in Gorsley Wood. ${ }^{85}$

\section{DISCUSSION}

\section{DISPLAYING POWER}

For those overland travellers from Dover, having ascended onto the ridge from the valley of the River Dour, the Nailbourne is the first stream they would encounter on the ridge route, c. $19 \mathrm{~km}$ northwest of Dover and c. $5 \mathrm{~km}$ before reaching the Stour and Canterbury (Figure 1). While the Roman port (Portus Dubris) may not have developed significantly until the second century AD, the Dover Bronze Age boat (c. $1550 \mathrm{BC}$ ) and Langdon Bay continental tools lost/deposited at sea (c. 1300-1150 BC) are the most famous of the finds that demonstrate that sea-going vessels travelled between the Continent and Dover from at least the Bronze Age. ${ }^{86}$

Millett has argued that, in the Roman period, military personnel and traders of bulk goods would probably have travelled by water to Canterbury (whence access to London, the hub of the Roman road network, is easy), but others would more likely have taken the shortest Channel crossing and continued overland. ${ }^{87}$ Following this hypothesis, those travelling through the landscape to, or past, Canterbury in the Roman period from the Continent via Dover were probably more often those with non-military roles and smaller

\footnotetext{
82 See footnote 95.

83 For funerary activity along the Dover road in this area in the Roman period, see Jenkins 1956, 248; Haverfield et al. 1932, 148; Rolfe 1844, 279; Jessup 1943, 69.

84 A burial area in the valley is represented by Roman-period cremation burials, inhumations, and associated artefacts, including a coin of Carausius (c. AD 286-293), which were discovered during excavations and improvements for the artificial lake, see Bell 1848; Bell 1880-1902; Haverfield et al. 1932, 147.

85 Four cremations and 13 inhumations dating to $c$. 3rd-5th centuries AD were excavated in 1973-1974 at the south-eastern edge of the field south of Bourne Park and east of Bishopsbourne village.

86 For the Dover boat, see Clark 2004a and 2004b; for Langdon Bay, see Needham, Parham and Frieman 2013.

87 Millett 2007, 148.
} 
entourages. It is more likely that people travelled along the drier, higher ridge route with wheeled vehicles, perhaps carrying goods inland from the Continent, and along the valley with animals, so that they would have easier access to water.

In travelling from the Dover area along the ridge towards Canterbury/Bigbury, people and their goods would have been halted if they could not easily cross the Nailbourne where the ridge plunges down (c. $40 \mathrm{~m}$ drop over $500 \mathrm{~m}$ today) into the Nailbourne valley, at the modern village of Bridge. The more recent changes to the stream make it difficult to know if there was a ford or bridge at this location, but the combination of the steep slope and water crossing suggest the possibility that this intersection was a good location for stopping or slowing heavy goods-laden carts and pack animals. The size, date, and location of the Nailbourne hilltop enclosure and associated evidence suggest a hillfort and indicate that there was either a local organization of, or broad coordination of, control of the routes to/from Dover via Canterbury at this ridge route-river intersection. ${ }^{88}$

The positioning of the later high-status structural complex in the valley appears to have been carefully chosen to link the former control point to the Roman-period display of wealth and status. The Nailbourne and the two springs in the valley within Bourne Park were significant water sources for settlement and animal husbandry in the area-in addition to possibly being of ritual significance for the 'genii loci' - and the people who controlled access to these could exert power over the local population. The groups who organized the construction of monuments for communal use, such as the large IA enclosures, the temples and the major trackway linking the nucleated settlement/temple/sanctuary site at Goodnestone to the temples and ridge route, would have had the ability to direct labour and make (?collective) decisions about the locations and character of these structures. Encouraging, coercing or forcing people to engage in such labour probably involved the control of resources such as land, agricultural surplus, or wealth.

It is impossible to reconstruct the precise nature of the connection between the Nailbourne hilltop enclosure - probably out of use at some point during the LPRIA, but certainly defunct after the construction of the Canterbury-Dover Roman road, which ran through it - and later landscape features, including the high-status Roman-period buildings and enclosures in the valley bottom. However, the proximity and relationships of orientation and visibility between the 'villa'-type structures, which are rare in the

88 Other major Dover to Canterbury route-river intersections are at Canterbury (the Stour) and Springhead (Ebbsfleet). IA settlement can be associated with the route: at Dover, for example, a small IA hillfort may underlie the Castle (Ashbee 2005, 158-159; Bayley 1962; Colvin 1959). Other hillforts/enclosed oppida at points of entry on Thanet in east Kent suggest the possibility that power was strategically displayed at locations which people from the Continent arrived at and/or travelled past. At Margate on Thanet, a MiddleLPRIA hillfort or settlement has been identified from remains of a large parallel ditched enclosure containing posthole structures (Canterbury Archaeological Trust 2012). Another IA hillfort has been posited from cropmarks at St Peter's, Broadstairs, on Thanet. There is currently no evidence of a significant enclosure along the Wantsum Channel or the Stour east of Canterbury. 
vicinity of Canterbury, and the large IA hilltop enclosure do not appear to be random and may represent expressions of power and status over a long period. Even if the IA enclosure was no longer in use or its ditches visible, the memory of the social significance of the place may have been retained by the local population. How such social memory may have persisted we cannot know, ${ }^{89}$ and we should not underestimate the inherently attractive location of the site, but the presence of a possible hillfort (not common) so near to the villa (very rare) is difficult to ignore.

It is not simply proximity that links these places, however. The most advantageous angle for viewing the later Roman buildings is from the location of the former Nailbourne hilltop enclosure (Figure 3), which provides a sweeping view down into the valley that would present the viewer with both facades of the two buildings beyond the stream (i.e. the facades face northeast and northwest respectively and are most visible from an elevated position directly north). The display of wealth in the large size of these structures seems to be linked to the hilltop enclosure and the point of control. ${ }^{90}$ As the first "villa'-type building positively identified within the hinterland of Canterbury (see above for Blean, Swarling and Ickham/Wingham), it is likely either that a power-holding family/ group, perhaps that which controlled the hilltop enclosure in the IA, was demonstrating its continued status in the Roman period, or alternatively that an individual/family/group sought to associate themselves with and/or usurp the association between this place and local power.

Evidence of enclosures and boundaries adjacent to the ridge route appears to indicate that the traveller gazed past productive fields down into the valley, where the impressive structures lay. This theatre of communicating status, wealth and productivity was directed towards those travelling along the road.$^{91}$ Indeed, recent analysis has demonstrated that proximity to roads is an important factor in villa positioning, perhaps more significant than proximity to towns..$^{92}$ The concern with such display to the road users can be compared with the siting of the Roman barrows at Bartlow, Cambridgeshire, where the GIS and viewshed analysis indicates that they were not located to impress travellers on the main Roman roads but rather 'the mounds appear to have been designed to be viewed from the surrounding valleys and fields, and from a minor road thought to run past them. The location of the mounds may thus have been chosen to communicate power and status to the inhabitants of the local villa estate, as well as selected neighbouring

89 Much has been written about the transmission of social memory, see, for example, Gosden and Lock 1998.

90 The villa structures cover an area larger than that of the villas at Thurnham and Eccles. The complex is modest in comparison, however, to some of the largest villas in western Kent, for example, Darenth.

91 There is a strong physical and symbolic relationship between the Roman-period complex and the road, which is not always the case elsewhere in Kent, where the Medway and Darent valley villas are positioned away from main roads and coastal routes, see Taylor 2011, 183. In his survey of villas in the Swale District Wilkinson deems proximity to road and/or fluvial routes important, see Wilkinson 2000 and 2004-2005 for the Hog Brook, Deerton Street villa, however several of these proposed 'villas' are known only from surface scatters.

92 Allen 2016, 115. 
villas. ${ }^{93}$ In Bourne Park, the impressive Roman-period stone-founded structures in the valley seem to be communicating with those on the main Roman road, though, as we shall see, the landscape of burial and belief, as at Bartlow, may have been differently oriented.

\section{EXPRESSIONS OF BELIEF}

The physical and visual connections between paths of movement, lines of sight, and significant ritual places within this landscape - the possible IA funerary enclosure, the temples, barrows and other burials, and possibly the natural springs - indicate that the construction of belief may have been central to the organization of community identity within this social landscape. The communal nature of ritual activities held at temples and burial sites was supported by the existence of a major trackway (likely predating the temples) and two paths. Guiding the movement of people and reinforcing symbolic connections through juxtaposition, alignment, and intervisibility was not limited to places of ritual or communal activity, of course, but these structures for experiencing the landscape were nonetheless significant for such activities.

Formal burial - both inhumation and cremation - is characteristic of the LPRIA in Kent. Rectilinear enclosures were used to bound cemeteries across northwest Europe, both in the IA and the Roman period, creating a symbolic boundary between the living and the dead and a monumentalized space for the enacting of mortuary rituals. ${ }^{94}$ While the creation of the Roman-period road appears to have attracted a greater number of Romanperiod and early Medieval burials between Dover and Canterbury, a LPRIA cremation containing a La Tène type brooch interred in a Roman helmet also found alongside the Dover-Canterbury ridge route, north of the Nailbourne (Figure 2), indicates that this ridge was used for burial in the LPRIA..$^{55}$ If the rectilinear enclosure to the south of the Nailbourne hilltop enclosure in Bourne Park is a mortuary enclosure, the large size could reflect the status of individuals buried there or a large number of interments. LPRIA cemeteries containing a large number of cremation burials are often associated with focal sites (e.g. King Harry Lane, St Albans, and Westhampnett, near Chichester) ${ }^{96}$ and the Nailbourne hilltop enclosure, not just the ridge route, may have acted as the focal point here. This may even be the case if the putative hillfort had already been abandoned: LPRIA cemeteries are known in rural locations where the population making use of them must have travelled specifically for the purpose of interring their dead (e.g. the nearby Swarling urnfield cemetery and Westhampnett), perhaps continuing earlier customs.

93 Eckardt 2009, 89.

94 See Bradley et al. 2015, 316-324.

95 Portable Antiquities Scheme KENT-BEC6E6, KENT-FA8E56, see Farley, Parfitt and Richardson 2014.

96 For King Harry Lane, see Fitzpatrick 1991 and Stead and Rigby 1989; for Westhampnett, see Fitzpatrick 1997 and 2000. 
The Roman-period burial mounds in Gorsley Wood were apparently linked to the high-status structures in Bourne Park and tied into a wider landscape of belief, ritual, and group identity by way of a clear (if intermittently identified) linear feature, possibly a ditch or pathway (Figure 3). Mourners attending a funerary ritual, or revisiting the barrow mounds, at the Gorsley Wood barrows would have had a view across the valley to the ridge route and former hilltop enclosure and far beyond, to the Bekesbourne and Barham temples, and the Goodnestone nucleated settlement, while the valley itself would have been obscured (Figure 8). The physical connection created by the pathway between the valley-bottom enclosures and the burial mounds links the bounded spaces of the living and the places memorializing the dead. Moving along the path into the valley, the Roman barrows pass out of view until a person reaches the location of the large Bronze Age barrows on the opposite side of the valley, about half-way up the slopeperhaps a good stopping point along a steep walk. From these barrows, which were placed on a gentle slope within a depression, the view is restricted to the Nailbourne Valley towards the south and west back towards the spring, the structural complex, and (possibly, tree-permitting) the tops of the barrows in Gorsley Wood (Figure 8). By placing the path on the downslope side of the barrow mounds, the view is obscured by the ridge to the north, east, and southeast, accentuating the significance of the valley features and the visual impact of the Bronze Age barrows rising above the viewer. In creating the path on this line and constructing the Gorsley Wood barrows just beyond the shoulder of the hill, a special place was created at the Bronze Age barrows for both physically and symbolically connecting the deep past of the huge, eroded mounds with the Roman barrows. This path facilitates the procession and ritual activities associated with funerary rites, springs, ${ }^{97}$ and temples, but it also draws people across the grain of the landscape, perpendicular to the easier route of the road connecting the towns, and encourages connections among a community in their enacting of memory and belief. ${ }^{98}$

Although such a reconstruction of funerary/ritual-associated movement in the landscape cannot be proven, comparanda suggest it is not an unreasonable interpretation of the archaeological record. Ample iconographic and literary evidence demonstrate the importance of processions in Roman funeral/ritual praxis (which may have involved repeated visits to burials) and for Roman Britain these have often been reconstructed for urban to extra-mural contexts. ${ }^{99}$ There is no reason to think that the same practices do not also occur in rural landscapes between non-urban features, especially considering the fact that processional activity across landscapes in prehistoric funerary/ritual contexts

97 Although no securely identified metal-detected 'votive' objects have been recovered (though an incomplete list compiled by the detectorists mentions a head of 'Poseidon'), it was common in both the IA and the Roman period for watery places to have held cultic significance and the proximity of the path to the springs may be been significant. See Fitzpatrick 1984 for IA watery deposition. See Crease 2015 for LPRIA and Roman structured deposition in watery contexts.

98 See also Wallace and Gardner in prep.

99 For Roman funeral processions, see Toynbee 1971, 46-48. See Weekes 2016 for a summary of research into Romano-British funerary practice. 

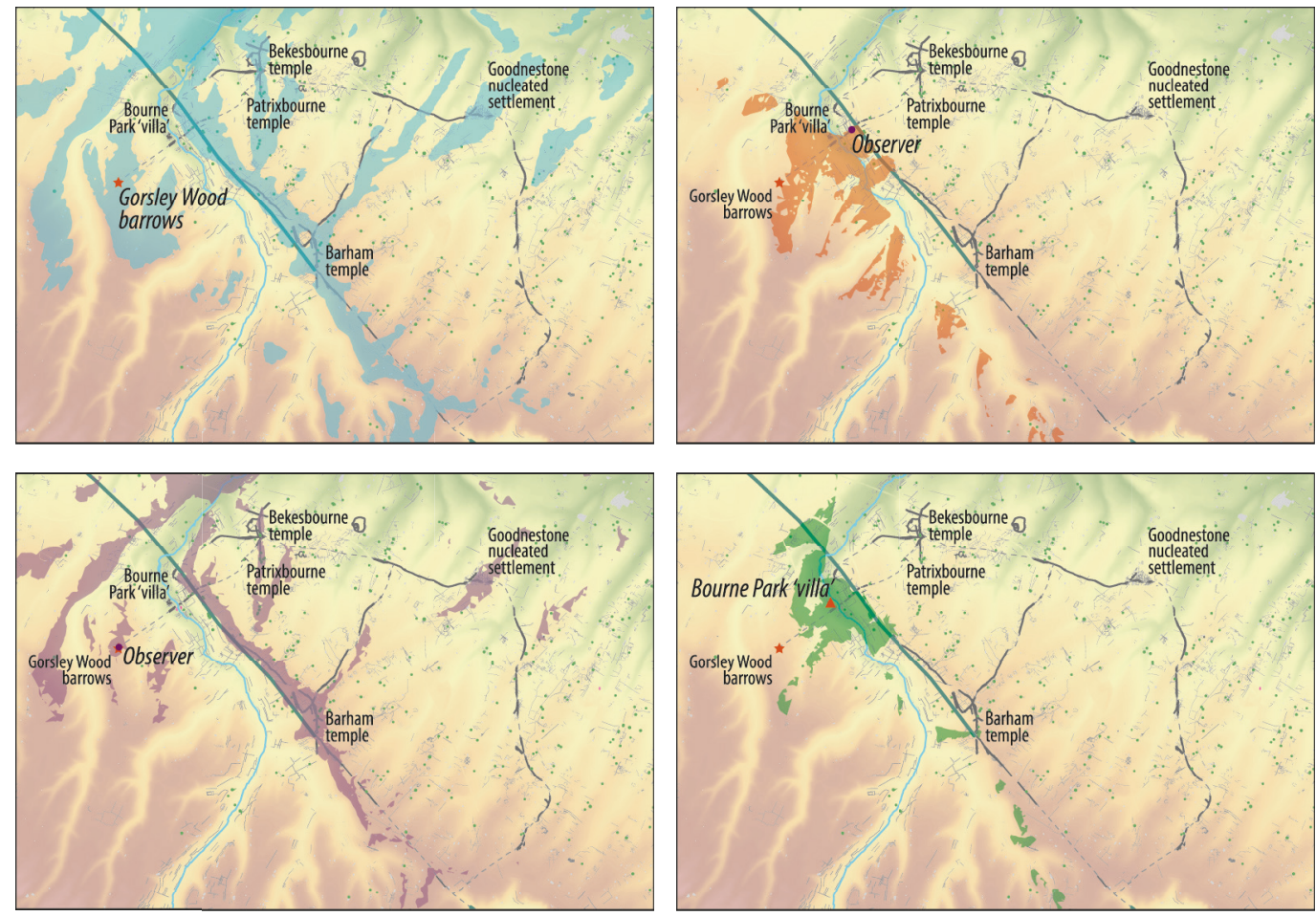

Area from which the Gorsley Wood barrows would be visible to a $1.8 \mathrm{~m}$ person (at estimated height of $5 \mathrm{~m}$ for the largest barrow, derived from the diameter and assumption that they took the common flat-topped conical form).

Ground surface visible to a $1.8 m$ person standing beside (east of) the Gorsley Wood barrows at the point labelled 'observer'.

Ground surface visible to a 1.8m person standing at the point labelled 'observer', the location of the two large Bronze Age barrows on the Gorsley Wood-Bekesbourne temple path (NB: buffer not shown, but the top $3 m$ of the largest Gorsley Wood barrow would have been visible from this point; $c$ f. top-left image.)

Area from which the Bourne Park' villa' (at estimated height of $6 \mathrm{~m}$ ) would be visible to a $1.8 \mathrm{~m}$ person.

Figure 8. Visibility analyses of the same area as Fig. 2 (see Fig. 2 for key, labels, and scale). Visible areas are approximate as modern features and the $5 \mathrm{~m}$ pixels (using OS Terrain 5) limit precision. (Lacey Wallace and Chris Blair-Myers with background DEM data, Crown copyright/database right 2017, an Ordnance Survey/EDINA supplied service.)

\section{has been widely accepted. ${ }^{100}$ Certainly it is the case that some Bronze Age barrows in}

100 For a concern with possible movement and intervisibility in the landscape, see the work on the Springhead sanctuary area, where the researchers note that the Pepper Hill cemetery would have been visible to funerary processions approaching from the temple complex and there may have been a 'viewing platform' overlooking the complex, see Andrews et al. 2011a. Springhead area - one being to do with the visibility of the Pepper Hill cemetery - on a slight rise that would have made it quite visible to funerary processions approaching from Springhead to the north, and another to do with a feature interpreted as a possible 'viewing platform/terrace overlooking the temple complex from outside a major enclosure ditch, though admittedly here only about $90 \mathrm{~m}$ from the nearest temple/shrine structure. Springhead area - one being to do with the visibility of the Pepper Hill cemetery - on a slight rise that would have made it quite visible to funerary processions approaching from Springhead to the north, and another to do with a feature interpreted as a possible "viewing platform/terrace overlooking the temple complex from outside a major enclosure ditch, though admittedly here only about $90 \mathrm{~m}$ from the nearest temple/shrine structure. 
this area were levelled or damaged in the IA (e.g. Site 9, Barrow 1 on the Bridge bypass which was cut through by an IA ditch), ${ }^{101}$ but several were clearly visible into the Roman period (e.g. the barrow at TR 2310 4848, which the Roman road clearly deviates to respect, Figure 2 and Figure 4). These large barrows, visible from the valleys as well as the higher ground, were prominent in the landscape and would have been familiar to people from the Continent as burial markers (e.g. the Flanders monuments). ${ }^{102}$ The community or family identities associated with these monuments are unlikely to have been maintained over hundreds of years, but they may have served to construct and reinforce local group identity and the sense of connection between people and the land. ${ }^{103}$ Perhaps even as minor, eroded features, their significance persisted and the barrows were likely one part of a long-term ceremonial use of the landscape here, as, perhaps, at Monkton. ${ }^{104}$

The use of the earlier Bronze Age monuments within a broader Roman-period landscape of belief and memory perhaps served to lay claim to an expanse of land beyond the Nailbourne Valley itself and to root that claim within the deep past and ancestral ownership. The use of (albeit much smaller) barrows in Gorsley Wood in the Roman period also may also have created the illusion of continuity and connection over time. This link between the temples, springs, and barrows could be seen as a symbolic marriage of belief, ancestors, spirits, and the land. ${ }^{105}$ Such connection of significant places was a central method of inscribing identity onto the landscape and communicating a symbolically-charged relationship between people and place.

101 Springhead area - one being to do with the visibility of the Pepper Hill cemetery - on a slight rise that would have made it quite visible to funerary processions approaching from Springhead to the north, and another to do with a feature interpreted as a possible 'viewing platform/terrace overlooking the temple complex from outside a major enclosure ditch, though admittedly here only about $90 \mathrm{~m}$ from the nearest temple/ shrine structure. Macpherson-Grant 1980.

102 For the long-term history of urnfields and late prehistoric barrows in Flanders, see Van Beek and De Mulder 2014.

103 See Hutton 2011, Kamash 2016 for memory of the past in Roman Britain and Wallace and Gardner in prep. on temporality in rural Roman Britain.

104 For Monkton, see Bennett et al. 2008; Canterbury Archaeological Trust 1996. IA barrows appear to have been revered in the Roman period at Brisley Farm, Ashford, see Stevenson and Johnson 2004.

105 The hexagonal 'shrine' noted on the Rural Settlement of Roman Britain project database and published by Macpherson-Grant and Wilkinson (2014) is not included here as we believe it to be one of two hexagonal features dating to landscaping undertaken at the time of the construction of Bourne Park House, c. 1701. These two hexagons lie on either side of, and are precisely equidistant from, an avenue of lime trees removed in c. 1756 to construct the new carriage drive (Bell 1880-1902). The nineteenth-century landowner believed them to be recent areas of tree-plantation. Macpherson-Grant and Wilkinson's view that these hexagonal ditches date to the Roman period cannot be verified in the absence of detailed section drawings in their publication. Hexagonal shrines are very rare in Roman Britain, with only three examples currently known: in the Meon valley (Hampshire), Colleyweston Great Wood (Rutland) and Abbots Ann (North Hampshire). They are extremely rarely associated with Romano-British 'villas': two can be found at Keynsham (Somerset) at both ends of the western corridor, see Bulleid and Horne 1926. Polygonal Roman structures are attested across the Continent, but not frequently, one of the best known is the so-called temple of Apollo Moritasgus at Alesia (Alise-Sainte-Reine, Côte-d'Or), see de Cazanove et al. 2012. 


\section{CONNECTED LANDSCAPES AND SOCIAL GROUPINGS}

In the environs of Canterbury, a large landscape area seems to have been connected by both the Nailbourne stream/Elham Valley and the major trackway east of the DoverCanterbury ridge route between the Nailbourne crossing and the Dour. These connections across the landscape may represent the symbolic and physical links of a cohesive social group. Laying claim to an important water source as well as a significant trade and communication route appears to have been undertaken through the creation of a large hilltop enclosure at the ridge route-stream intersection sometime in the IA. Territory connected by routeways and stream valleys, rather than that surrounding a single central place, may have been socially significant in this part of the south-east. The notion that there were perhaps several separate social groups within east Kent is supported by the positions of several possible major IA hillforts/enclosed oppida in the area, including the Nailbourne hilltop enclosure, Bigbury and Homestall Wood (Figure 1). If there were multiple social groups, then the creation of a single civitas capital would have required significant negotiation and cooperation, hence perhaps the choice of a ritual centre at Canterbury which may have already been serving to unite various groups.

Millett has already raised the possibility that social groups in Kent were organized by river valleys, rather than blocks of territory surrounding hillforts and/or oppida. ${ }^{106}$ It may be that the Nailbourne/Elham Valley was a (western) linking feature within our landscape area, while the major trackway united the people east of the ridge route (Figure 2). This trackway may have served to 'include' land beyond the valley within the territory of the same social group and to divide it from areas associated with the Wingham river valley. The three large probably Middle-LPRIA enclosures, only about 1-2km distant one from the next, appear to be linked to the trackway and perhaps represent communal settlement/activity centres within the Nailbourne valley territory and/or a boundary between this group and the approaches up the valleys from the Wantsum Channel to the north.

Probably sometime late in the LPRIA, perhaps after the large Nailbourne hilltop enclosure was abandoned or in its final phases, the location was possibly marked as significant by the construction of what may be a funerary enclosure on the steep hillside beside the routeway. If this enclosure was funerary, its size presumably indicates a communal function and/or high-status usage and may have been associated with the leadership or group who inhabited the area. In LPRIA Kent, formal burial in cemeteries (e.g. Aylesford and Swarling) and the establishment of cultic centres (e.g. Springhead and probably Canterbury) may have become a key method of communicating group identity and bringing people together. The burial processes enacted at the possible LPRIA/early Roman funerary enclosure south of the Nailbourne hilltop enclosure in Bourne Park may have formed part of this function for the local group, whether the enclosure served as a high-status monument for a leading family or as a communal burial ground.

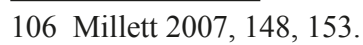


In Bourne Park, after the formalization of the ridge route as a long section of the Dover-Canterbury road (probably in the second century) with ditches and metalling, the intersection of ridge route and stream retained its significance, although its meaning and symbolism may have altered with the changing socio-political situation. At some point by the third century, a high-status structural complex including at least two large buildings within a possibly-walled enclosure was constructed in the valley. The high-status structural complex in Bourne Park could have been the residence of one powerful family, but the unusual form of the large western building and the proximity to the ridge route-river intersection and the two natural springs may suggest a non-domestic/communal function, a better understanding of which may be revealed by post-excavation analysis. Whatever the precise function of these structures, they clearly communicate with the road, and possibly the now-abandoned hilltop enclosure, perhaps referencing and drawing meaning from earlier and contemporaneous local power structures. The long façade was no doubt designed to attract the attention of passing traffic moving between Dover and Canterbury, both local and non-local, and may have been in some sense the 'public' face of the landscape created by those in control locally.

Another 'face' can be identified in Bourne Park, reflecting perhaps a more rural and local orientation, linked explicitly to ritual and burial practices. Within the Bourne Park area extensive high-resolution geophysical survey indicates the possibility that a corridor of movement along the stream was maintained into the Roman period-IA and Roman enclosures and field boundaries are evident in aerial photography in the Nailbourne/Elham Valley as far as the sources of the stream at Lyminge. The movement of people, animals, and goods along the valley may have been more closely aligned to local networks, social relationships and livestock management than that along the ridge route. As urban centres and the use of roads grew, travel between a rural settlement and a town became easier than between two rural locations unconnected by road. In order to maintain the importance of social networks outside towns, social and religious relationships had to be maintained and reinforced. Landscape links in the form of trackways, paths, and other linear features appear to have been a significant means of negotiating such needs. There are at least three temples in the territory proposed here (Figure 2), two of which may have been connected across the Nailbourne valley to the Roman-period burial mounds in Gorsley Wood (Figure 3). Roman-period burials in the valley and Roman burial mounds to the west in Gorsley Wood represent a likely change in burial ritual and monumentalization. The links made between the burial mounds and temples perhaps indicate a changing cultic practice and the increased importance of individuals and families in the landscape of belief. By creating pathways between these ritual monuments, the springs, Bronze Age barrows and Roman burials, a symbolic association appears to have been expressed in the social landscape.

The intervisibility, physical connection by pathways, and proximity of Roman-period features to significant earlier places and monuments indicate that the inhabitants of the area were manipulating temporality and topography to weave constructs of memory, 
power, and belief into the landscape. ${ }^{107}$ The result is a construction of identity on a landscape scale visible to the merchants and urban inhabitants moving along the road as well as to the local community, more likely to be those moving along the Nailbourne valley. By creating connectivity between meaningful features, the landscape communicated in two spheres: a public face of power to the road-users and an invitation to local groups to connect across the landscape in ritual and remembrance.

From ancient commentary to modern analysis of the discrepancies in villa distribution, there has been much discussion of the territories of the LPRIA and Roman-period groups of Kent. Whilst, ultimately, interpretations of the partial archaeological record will always be highly subjective and constantly necessitate rethinking, we consider that much of the social commentary to date has been too generalizing and has lacked detailed investigation of, in particular, the possible inscription of social identities within the landscape. We have tried to show how a combination of evidence with extensive geophysical analysis can contribute to the ongoing discussions about social groupings in the hinterland of Canterbury. Though many ambiguities remain, our interpretations can contribute to and challenge broader-brush visions of the social changes in the IA and Roman periods.

\section{ACKNOWLEDGEMENTS}

The authors, Principal Investigator and Co-Investigator of the CHP respectively, are very grateful to the landowners for permission to carry out geophysical survey (20112017) and small-scale excavation (2016). Equipment was provided by the Universities of Cambridge, Kent, Oxford and Southampton, Kent County Council and Bartington Instruments. We are extremely grateful for funding from the Faculty of Classics and McDonald Institute for Archaeological Research, University of Cambridge; Roman Research Trust; All Souls College; Haverfield Bequest; Association for Roman Archaeology; Kent Archaeological Society; Canterbury Historical and Archaeological Society. Special thanks go to Paul Johnson (co-director of fieldwork) and Lieven Verdonck (GPR specialist). The fieldwork was made possible by the enthusiasm and dedication of students and volunteers, including Ashley Chhibber, Gabriella Jeakins, Michael Loy, Alex Mirošević-Sorgo, Sean O'Connor, Hanneke Salisbury, Rob Stroud. The authors thank Robert Prestige for sharing his family's documentation of Bourne Park and Roly Cobbett for his insights into local history and cartography. Thanks are also due to Ben Croxford (previously at the Kent HER) for his help and especially to our collaborator Chris Blair-Myers, whose expertise with aerial photography has been invaluable. We are indebted to Michael Loy for his research assistance and to Paul Booth, Andrew Gardner, and the anonymous reviewers for their comments.

107 There may be a possible comparison to be made here with the results of the excavations at Augustine House, Rhodaus Town, Canterbury (Helm 2014). At this site, closer to Canterbury and adjacent to the Dover-Canterbury road, a fourth-century polygonal shrine was positioned above a former late IA burial, with 'a significant aspect overlooking Roman Watling Street and its access through Ridingate' (Helm 2014, 140). 


\author{
University of Lincoln \\ lwallace@lincoln.ac.uk
}

University of Nottingham

alex.mullen@nottingham.ac.uk

\title{
BIBLIOGRAPHY
}

Allen, M. 2016: 'Ch. 4. The South,' in Smith et al. The Rural Settlement of Roman Britain, London, 75-140

Allen, M., Lodwick, L., Brindle, T., Fulford, M. and Smith, A. 2017: The Rural Economy of Roman Britain, London

Allen, T., Donnelly, M., Hardy, A., Hayden, C. and Powell, K. 2012: A Road through the Past: Archaeological Discoveries on the A2 Pepperhill to Cobham Road-scheme in Kent, Oxford

Andrews, C. 2001: 'Romanisation: a Kentish Perspective', Archaeologia Cantiana 121, 25-42

Andrews, P., Biddulph, E., Hardy, A. and Brown, R. 2011a: Settling the Ebbsfleet Valley: High Speed 1 excavations at Springhead and Northfleet, Kent: The Late Iron Age, Roman, Saxon, and Medieval Landscape. Volume 1: The sites, Oxford/Salisbury

Andrews, P., Booth, P., Fitzpatrick, A. P., Welsh, K. 2015a: Digging at the Gateway: Archaeological Landscapes of South Thanet: The Archaeology of the East Kent Access (Phase II) Volume 1: The Sites, Oxford

Andrews, P., Booth, P., Fitzpatrick, A. P., Welsh, K. 2015b: Digging at the Gateway: Archaeological Landscapes of South Thanet: The Archaeology of the East Kent Access (Phase II) Volume 2: The Finds, Environmental and Dating Reports, Oxford

Andrews, P., Mepham, L., Schuster, J. and Stevens, C. J. 2011b: Settling the Ebbsfleet Valley: CTRL Excavations at Springhead and Northfleet, Kent: The Late Iron Age, Roman, Saxon, and Medieval Landscape. Volume 4: Saxon and Later Finds and Environmental Reports, Oxford/ Salisbury

Ashbee, P. 2005: Kent in Prehistoric Times, Stroud

Ashbee, P. and Dunning, G. C. 1960: 'The Round Barrows of East Kent', Archaeologia Cantiana $74,48-57$ 
Barnet, C., McKinley, J. I., Stafford, E., Grimm, J. M. and Stevens, C. J. 2011: Settling the Ebbsfleet Valley: High Speed 1 Excavations at Springhead and Northfleet, Kent: The Late Iron Age, Roman, Saxon, and Medieval Landscape. Volume 3: Late Iron Age to Roman Human Remains and Environmental Reports, Oxford/Salisbury

Bates, A. 2017: Making the invisible visible; New Survey and investigation of the Iron Age Hillforts of Bigbury and Oldbury in Kent, Unpublished PhD thesis, University of Kent

Bayley, E. H. 1962: 'Activities around Dover, 1962', Archaeologia Cantiana 77, xlviii

Bell, M. 1848: 'Proceedings of the Association: January 18', Journal of the British Archaeological Association 3, 47-48

Bell, M. 1880-1902: The Book of Bourne, unpublished manuscript transcribed 2006 by M. Stewart and held by R. Prestige

Bennett, P., Clark, P., Hicks, A., Rady, J. and Riddler, I. 2008: At the Great Crossroads: Prehistoric, Roman

and Medieval Discoveries on the Isle of Thanet 1994-95, Canterbury

Biddulph, E., Seager Smith, R. and Schuster, J. 2011: Settling the Ebbsfleet Valley: High Speed 1 Excavations at Springhead and Northfleet, Kent: The Late Iron Age, Roman, Saxon, and Medieval Landscape. Volume 2: Late Iron Age to Roman Finds Reports, Oxford/Salisbury

Birchall, A. 1965: 'The Aylesford-Swarling Culture: the Problem of the Belgae Reconsidered', Proc. Prehist. Soc. 31, 241-367

Bishop, M. C. 1995: 'Some pre-Flavian Military Equipment from Kent', Arma 7, 17-19

Black, E. W. 1987: The Roman Villas of South-East England, Oxford

Blagg, T. F. C. 1982: 'Roman Kent' in P. E. Leach (ed.) Archaeology in Kent to AD 1500, London, $51-60$

Blagg, T. F. C. 1995: 'The Marlowe Excavations: an Overview', in Blockley, K. et al. (eds), The Archaeology of Canterbury Volume 5, Canterbury, 7-25

Blanning, E. D. 2014: Landscape, Settlement and Materiality: Aspects of Rural Life in Kent during the Roman Period, unpublished PhD thesis, University of Kent, 3 volumes

Blockley, K., Blockley, M., Blockley, P., Frere, S. S. and Stow, S. (eds) 1995: The Archaeology of Canterbury. Volume V Excavations in the Marlowe Car Park and Surrounding Areas, Maidstone (2 volumes)

Blockley, K. and Blockley, P. 1989: 'Excavations at Bigberry, near Canterbury, 1981', Archaeologia Cantiana 107, 239-251 
Blockley, K., Sparks, M. and Tatton-Brown, T. 1997 Canterbury Cathedral Nave: Archaeology, History and Architecture, Maidstone

Boast, E. and Gibson, A. 2000: 'Neolithic, Beaker and Anglo-Saxon Remains: Laundry Road, Minster-in-Thanet', Archaeologia Cantiana 120, 359-372

Booth, P. 2009: 'Bigbury and South Blean [in 'Roman Britain in 2008']', Britannia 40, 276

Booth, P. 2012: 'Bigbury [in 'Roman Britain in 2011']', Britannia 43, 350-351

Booth, P. 2017: 'Kent Roman Rural Settlement' in D. G. Bird (ed.) Agriculture and Industry in South-eastern Roman Britain, Oxford, 55-83

Booth, P., Bingham, A.-M. and Lawrence, S. 2008: The Roman Roadside Settlement at Westhawk Farm, Ashford, Kent, Excavations 1998-9, Oxford

Booth, P., Champion, T., Foreman, S., Garwood, P., Glass, H., Munby, J. and Reynolds, A. 2011 On Track. The Archaeology of High Speed 1 Section 1 in Kent, Oxford/Salisbury

Bradley, R., Haselgrove, C., Vander Linden, C. and Webley, L. 2015: The Later Prehistory of North-West Europe. The Evidence of Development-led Fieldwork, Oxford

Breeze, D. J. 2014: The Impact of Rome on the British Countryside. A Conference organized by the Royal Archaeological Institute, Chester, 11-13 October 2013, Wetherby

Brück, J. 2005: 'Experiencing the Past: the Development of a Phenomenological Archaeology in British Prehistory', Archaeological Dialogues 12.1, 45-72

Bulleid, A. and Horne, E. 1926: 'The Roman House at Keynsham, Somerset', Archaeologia 75, 109-135

Bushe-Fox, J. P. 1925: Excavation of the Late-Celtic Urn-Field at Swarling, Kent, Oxford

Campana, S. 2015: 'Emptyscapes: Filling "Empty" Mediterranean Landscapes, Mapping the Archaeological

Continuum', Archaeologia Polona 53, 149-152

Canterbury Archaeological Trust 1996: 'Interim Report on Work Carried out by Canterbury Archaeological Trust', Archaeologia Cantiana 116, 311-324

Canterbury Archaeological Trust 2012: Archaeological Evaluation at Capital House, Northdown Road, Margate, Kent, unpublished report

Champion, T. 2007: 'Prehistoric Kent', in J. H. Williams (ed.), The Archaeology of Kent to AD 800, Woodbridge, 67-132

Champion, T. 2016: 'Britain before the Romans', in M. Millett, L. Revell and Moore, A. (eds) The Oxford Handbook of Roman Britain, Oxford, 150-178 
Clark, P. (ed.) 2004a The Dover Bronze Age Boat, London

Clark, P. (ed.) 2004b The Dover Bronze Age Boat in Context, Oxford

Colvin, H. M. 1959: ‘An Iron-Age Hillfort at Dover?’ Antiquity 33, 125-127

Conyngham, A. and Akerman, J. Y. 1844: 'An Account of the Opening and Examination of a Considerable Number of Tumuli on Breach Downs, in the County of Kent, in a Letter from Lord Albert Conyngham F.S.A. to John Yonge Akerman Esq. F.S.A.; Followed by Mr. Akerman's Remarks upon Lord Albert Conyngham's Excavations', Archaeologia 30, 47-56

Crease, S. M. E. 2015: Re-Thinking Ritual Traditions: Interpreting Structured Deposition in Watery Contexts in Late Pre-Roman Iron Age and Roman Britain, unpublished $\mathrm{PhD}$ thesis, University College London

Creighton, J. 2000: Coins and Power in late Iron Age Britain, Cambridge

Creighton, J. 2006: Britannia: the Creation of a Roman Province. Abingdon

Creighton, J. 2016: Silchester: Changing Visions of a Roman Town. Integrating geophysics and archaeology: the results of the Silchester mapping project 2005-10, London

Cunliffe, B. 2005: Iron Age Communities in Britain, London / New York (fourth edition)

de Cazanove, O, Vidal, J., Dabas, M. and Caraire, G. 2012: 'Alésia, forme urbaine et topographie religieuse: L'apport des prospections et des fouilles récentes’, Gallia 69.2, 127-149

Detsicas, A. 1987: The Cantiaci (Gloucester)

Detsicas, A. P. 1989: 'Excavations at Eccles: a Progress Report', Archaeologia Cantiana 107, 83-88

Dowker, G. 1882: ‘The Roman Villa at Wingham', Archaeologia Cantiana 14, 134-139

Dowker, G. 1882: 'The Roman Villa at Wingham Part II', Archaeologia Cantiana 15, 351-357

Driver, J. D., Rady, J. and Sparks, M. 1990: The Archaeology of Canterbury. Volume IV Excavations in the Cathedral Precincts, 2 'Meister Omers', Linacre Garden, and St Gabriel's Chapel, Maidstone

Eckardt, H., Brewer, P, Hay, S. and Poppy, S. 2009: 'Roman Barrows and their Landscape Context: a GIS Case Study at Bartlow, Cambridgeshire’, Britannia 40, 65-98

Elsden, N. 2006: 'Furfield Quarry, Boughton Monchelsea, Maidstone, Kent, Earthworks Assessment', unpublished MoL report

English Heritage 1999: Dispersed Medieval Settlement Remains and a Roman Building immediately South West of St. Cosmus and St. Damian's Church (Scheduling record). SKE11842. 
Evans, A. J. 1890: 'On a Late-Celtic Urn-Field at Aylesford, Kent', Archaeologia 52, 315-88

Farley, J., Parfitt, K. and Richardson, A. 2014: 'A Late Iron Age Helmet Burial from Bridge, near Canterbury, Kent', Proceedings of the Prehistoric Society 80, 379-388

Faussett, B. (ed. Smith, C.R.) 1856: Inventorium sepulchrale: an Account of some Antiquities dug up at Gilton, Kingston, Sibertswold, Barfriston, Beakesbourne, Chartham, and Crundale, in the County of Kent, from A.D. 1757 to A.D. 1773, London

Fitzpatrick, A. P. 1984: 'The Deposition of La Tène Iron Age Metalwork in Watery Contexts in Southern England', in B. W. Cunliffe and D. Miles (eds.), Aspects of the Iron Age in Central Southern England, Oxford, 178-190

Fitzpatrick, A. P. 1991: 'Review: Death in a Material World: The Late Iron Age and Early RomanoBritish Cemetery at King Harry Lane, St Albans, Hertfordshire: Verulamium: The King Harry Lane Site by I. M. Stead; V. Rigby', Britannia 22, 323-327

Fitzpatrick, A. P. 1997: Archaeological Excavations on the Route of the A27 Westhampnett Bypass, West Sussex. Volume 2: the Late Iron Age, Romano-British, and Anglo-Saxon Cemeteries, Salisbury

Fitzpatrick, A. P. 2000: 'Ritual, Sequence, and Structure in Late Iron Age Mortuary Practices in North-west Europe', in J. Pearce, M. Millett and M. Struck (eds), Burial, Society and Context in the Roman World, Oxford, 13-29

Frere, S. S. 1970: 'The Roman Theatre at Canterbury', Britannia 1, 83-113

Frere, S. S., Bennett, P., Rady, J. and Stow, S. 1987: The Archaeology of Canterbury. Volume VIII Canterbury Excavations: Intra- and Extra-Mural Sites 1949-1955 and 1980-1984, Maidstone

Frere, S. S. and Stow, S. 1983: The Archaeology of Canterbury. Volume VII Excavations in the St George's Street and Burgate Street Areas, Maidstone

Frere, S. S., Stow, S. and Bennett, P. 1982: The Archaeology of Canterbury. Volume I Excavations at Canterbury Castle, Maidstone

Frere, S. S., Stow, S. and Bennett, P. 1982: The Archaeology of Canterbury. Volume II Excavations on the Roman and Medieval Defences of Canterbury, Maidstone

Gosden, C., Cooper, A., Creswell, M., Green, C., ten Harkel, L., Kamash, Z., Morley, L., Pybus, J. and Xiong, X. 2012: 'The English Landscape and Identities Project', Antiquity 86, 332

Gosden, C. and Lock, G. 1998: 'Prehistoric Histories', World Archaeology 30.1, 2-12 
Gruel, K. and Haselgrove, C. 2007: 'British Potins Abroad: A New Find from Central France and the Iron Age in Southeast England', in C. Gosden (ed.) Communities and Connections: Essays in Honour of Barry Cunliffe, ed. Chris Gosden, Oxford, 240-262

Guest, P. and Young, T. 2010: 'Mapping Isca: Geophysical Investigation of School Field and Priory Field, Caerleon', Archaeologia Cambrensis 158, 97-111

Hamilton, S. 2007: 'Cultural Choices in the 'British Eastern Channel Area in the Late pre-Roman Iron Age', in C. Haselgrove and T. Moore (eds), The Later Iron Age in Britain and Beyond, Oxford, 81-107

Hamilton, S. and Whitehouse, R. 2006: 'Phenomenology in Practice: Towards a Methodology for a "Subjective" Approach', European Journal of Archaeology 9.1, 31-71

Hammond, J. 2010: 'In Search of "The People of La Manche": a Comparative Study of Funerary Practices in the Transmanche Region during the Late Neolithic and Early Bronze Age (2500 BC-1500 BC)', Unpublished PhD thesis, University of Kent

Haverfield, F. J. et al. 1932: 'Topographical Index', in W. Page (ed.), The Victoria History of the County of Kent iii, London, 144-76

Helm, R. 2014: Outside the Town: Roman Industry, Burial and Religion at Augustine House, Rhodaus Town, Canterbury, Maidstone

Helm, R. and Rady, J. 2010 Excavations at Market Way, St Stephen's, Canterbury, Maidstone

Holman, D. 1998 (updated 2002): Goodnestone: the Iron Age Coins, unpublished report

Holman, D. 2000: 'Iron Age Coinage in Kent', Archaeologia Cantiana 120, 205-233

Holman, D. 2005: 'Iron Age Coinage and Settlement in East Kent', Britannia 36, 1-54

Howell, I. 2014: 'Continuity and Change in the Late Iron Age-Roman Transition within the Environs of Quarry Wood Oppidum: Excavations at Furfield Quarry, Boughton Monchelsea', Archaeologia Cantiana 134, 37-66

Hutton, R. 2011: ‘Romano-British Reuse of Prehistoric Ritual Sites', Britannia 42, 1-22

Jenkins, F. 1956: 'Researches and Discoveries in Kent', Archaeologia Cantiana 70, 246-80

Jenkins, F. 1984: 'The Re-excavation of the Roman 'Villa' at Wingham', Archaeologia Cantiana $100,87-99$

Jessup, R. F. 1943: 'Miscellaneous Notes: Field Notes in East Kent', Archaeologia Cantiana 56, $68-9$

Jessup, R. F. and Cook, N. C. 1936: 'Excavations at Bigberry Camp, Harbledown', Archaeologia Cantiana 48, 151-168 
Johnson, P. S. 2013a: 'Intramural Geo-magnetic Prospection', in C. Corsi and F. Vermeulen (eds), Ammaia I: the Survey. A Romano-Lusitanian Townscape Revealed, Ghent, 51-68

Johnson, P. S. 2013b: 'Earth-resistance Survey', in C. Corsi and F. Vermeulen (eds), Ammaia I: the Survey. A Romano-Lusitanian Townscape Revealed, Ghent, 83-89

Kelly, D. B. 1971: 'Quarry Wood Camp, Loose: A Belgic Oppidum', Archaeologia Cantiana 76, 55-84

Kamash, Z. 2016: 'Memories of the Past in Roman Britain', in M. Millett, L. Revell and Moore, A. (eds) The Oxford Handbook of Roman Britain, Oxford, 681-696

King, A. and Soffe, 1991: 'Hayling Island' in R. H. J. Jones (ed.) Britain in the Roman Period: Recent Trends, Sheffield, 111-113

Klein, W. G. 1928: 'Roman Temple at Worth, Kent', The Antiquaries Journal 8(1), 76-86

Lambot, B., Delestrée, L.-P., Méniel, P. 1993: Le site protohistorique d'Acy-Romance (Ardennes), Reims

Lawrence, S. 2006: 'The Roman Villa at Thurnham, Kent' CTRL Integrated Site Report Series, in Archaeology Data Service 2006

Lawson, T. and Killingray, D. 2004: An Historical Atlas of Kent, Chichester

Mackreth, D. 1997: 'Nooket's Wood, Goodnestone Kent', unpublished report

Macpherson-Grant, N. 1980: 'Archaeological Work along the A2: 1966-1974', Archaeologia Cantiana 96, 166-73

Mattingly, D. 2006: An Imperial Possession, London

Meaney, A. 1964: A Gazetteer of Early Anglo-Saxon Burial Sites, London

Meates, G. W. 1979: The Roman Villa at Lullingstone, Kent: Volume I, the Site, Maidstone

Millett, M. 2007: 'Roman Kent', in J. H. Williams (ed.), The Archaeology of Kent to AD 800, Woodbridge, 135-84

Money, J. H. 1960: 'Excavations at High Rocks, Tunbridge Wells, 1954-1956', Sussex Archaeological Collections 98, 173-221

Money, J. H. 1968: 'Excavations on the Iron Age Hillfort at High Rocks, near Tunbridge Wells, 1957-1961', Sussex Archaeological Collections 106, 158-205

Money, J. H. 1978: 'Excavations in the Two Iron Age Hillforts on Castle Hill, Capel, near Tonbridge, 1965 and 1969-71', Archaeologia Cantiana 91, 61-65 
Money, J. H. 1975: 'Excavations in the Two Iron Age Hillforts on Castle Hill, Capel, near Tonbridge, 1965 and 1969-71: Supplementary Note', Archaeologia Cantiana 94, 268-270

Moore, T. 2001: 'An Archaeological Assessment of Hailey Wood Camp, Sapperton, Gloucestershire: a Roman Temple Complex in the Cotswolds?', Transactions of the Bristol and Gloucestershire Archaeological Society 119, 83-93

Morrison, W., Thomas, R. M. and Gosden, C. 2014: 'Laying Bare the Landscape: Commercial Archaeology and the Potential of Digital Spatial Data', Internet Archaeology 36, http://intarch. ac.uk/journal/issue36/9/toc.html [last accessed 7th November 2017]

Nash, D. 1979: 'Five First Century B.C. Coins from Gaul found recently in East Kent', Archaeologia Cantiana 95, 298-299

Needham, S., Parham, D. and Frieman, C. J. 2013: Claimed by the Sea: Salcombe, Langdon Bay and other Marine Finds of the Bronze Age, Oxford

Niblett, R. and Thompson, I. 2005: Alban's Buried Towns: An Assessment of St Albans'Archaeology up to $A D 1600$, Oxford

Parfitt, K. 1980: 'A Probable Roman Villa on the Sandwich By-pass', Kent Archaeological Review $60,232-248$

Parfitt, K. (ed.) 1995: Iron Age Burials from Mill Hill, Deal, London

Parfitt, K. 2009: 'Preliminary Report on Excavations at Hull Place Roman Villa, Sholden, 2005-7', Archaeologia Cantiana 129, 103-112

Parfitt, K. 2012: 'Folkestone: Roman Villa or Iron Age Oppidum?', Current Archaeology 262, $22-29$

Parfitt, K., Perkins, D., Boast, E. and Moody, G. 2008: 'The Roman Villa at Minster-in-Thanet. Part 5:

The Main House, Building 1', Archaeologia Cantiana 128, 309-34

Philp, B. 1960: ‘A Romano-British Villa Site at Swarling', Archaeologia Cantiana 74, 186-190

Philp, B. 2000: 'The Roman Villa Site at Wingham, a Watching Brief', Kent Archaeological Review 140, 219-224

Pollard, R. J. 1988: The Roman Pottery of Kent, Maidstone

Powlesland, D. 2003: Twenty-five Years' Research on the Sands and Gravels of the Vale of Pickering, Yedingham

Rady, J. 2009: Excavations at North Lane, Canterbury 1993 and 1996, Maidstone 
RCHME 1989: The Classification of Cropmarks in Kent: a Report for the Monuments Protection Programme, unpublished report, available at https:/content.historicengland.org.uk/images-books/ publications/classification-of-cropmarks-in-kent/classification-cropmarks-kent.pdf/ [last accessed $6^{\text {th }}$ October 2017]

Rivet, A. L. F. and C. Smith 1979: The Place-names of Roman Britain, London

Robb, J. G. 1998: 'The "Ritual Landscape" Concept in Archaeology: a Heritage Construction', Landscape Research 23.2, 159-174

Rolfe, W. H. 1844: 'British Archaeological Association, First Annual Meeting, Canterbury, September 1844, Primeval Section', Archaeological Journal 1, 279

Rooke, H. 1787: 'An Account of the Remains of Two Roman Villae discovered near Mansfield Woadhouse, in May and October, 1786', Archaeologia 8, 363-376

Rudling, D. (ed.) 2008: Ritual Landscapes of Roman South-East Britain, Great Dunham/Oxford

Smith, A., Allen, M., Brindle, T. and Fulford, M. 2016: The Rural Settlement of Roman Britain, London

Smith, A., Allen, M., Brindle, T. and Fulford, M. 2018: Life and Death in the Countryside of Roman Britain, London

Smith, R. A. 1908: 'Anglo-Saxon Remains', in W. Page (ed.), The Victoria History of the County of Kent i, London, 339-87

Sparey-Green, C. 2010: 'Homestall Wood Earthworks, Harbledown, Kent', Kent Archaeological Society Newsletter $86,14-15$

Sparey-Green, C. 2013: 'Recent Research on Bigbury Camp and its Environs, Canterbury, Kent', Epistula 5, 10

Stead, I. M. 1976: Excavations at Winterton Roman Villa and other Roman sites in North Lincolnshire, 1958-67, London

Stead, I. M. and Rigby, V. 1989: Verulamium: The King Harry Lane site, London

Stevenson, J. and Johnson, C. 2004: 'Brisley Farm: the Last Iron Age Warriors of Kent?', Current Archaeology 191, 490-494

Stevenson, J. 2013: Living by the Sword: the Archaeology of Brisley Farm, Ashford, Kent, London

Still, M. 1997: ‘A Roman Lead Sealing from Goodnestone near Canterbury’, Britannia 28, 383-385

Struck, M. 2000: 'High Status Burials in Roman Britain (1st-3rd Centuries AD) - Potential of Interpretation', in J. Pearce, M. Millett and M. Struck (eds), Burial, Society and Context in the Roman World, Oxford, 85-96 
Stukeley, W. 1776: Itinerarium Curiosum; or, An Account of the Antiquities, and Remarkable Curiosities in Nature or Art, Observed in Travels through Great Britain, London (second edition)

Tatton-Brown, C. 2001: 'The Evolution of 'Watling Street' in Kent', Archaeologia Cantiana 121, $121-133$

Taylor, J. 2011: 'The Idea of the Villa: Reassessing Villa Development in South East Britain', in N. Roymans and T. Derks (eds.), Villa Landscapes in the Roman North, Amsterdam, 179-194

Thompson, F. H. 1983: 'Excavations at Bigberry Camp, near Canterbury 1978-80', Antiquaries Journal 66, 267-286

Thompson, F. H. 1986: 'The Iron Age Hillfort of Oldbury, Kent: Excavations 1983-4', Antiquaries Journal 63, 237-278

Tilley, C. 1994: A Phenomenology of Landscape, Oxford/Providence, RI

Toynbee, J. M. C. 1971: Death and Burial in the Roman World, Ithaca, NY/London

Van Beek, R. and De Mulder, G. 2014: 'Circles, Cycles and Ancestral Connotations. The Longterm History and Perception of Late Prehistoric Barrows and Urnfields in Flanders (Belgium)' Proceedings of the Prehistoric Society 80, 299-326

Verdonck, L. 2016: 'Detection of Buried Roman Wall Remains in Ground-penetrating Radar Data using Template Matching', Archaeological Prospection 23.4, 257-272

Vine, F. T. 1882 'The Kent Kistvaen’, JBAA 38, 113-114

Vine, F. T. 1883: 'On Three Roman Tumuli in Gorsley Wood, near Bridge and Canterbury', Archaeologia Cantiana 15, 311-317

Vine, F.T. 1886: Caesar in Kent: the Landing of Julius Caesar and his Battles with the Ancient Britons; with some Account of Early British Trade and Enterprise, Edinburgh

Wallace, L. M. 2014: The Origin of Roman London, Cambridge

Wallace, L. M. 2016: 'The Early Roman Horizon', in M. Millett, L. Revell and Moore, A. (eds) The Oxford Handbook of Roman Britain, Oxford, 117-133

Wallace, L.M. and Gardner, A. In prep. 'Making space for past futures: rural landscape temporalities in Roman Britain'

Wallace, L. M., Johnson, P. S., Strutt, K. and Mullen, A. 2014 'Archaeological Investigations of a Major Building, Probably Roman, and Related Landscape Features', Archaeologia Cantiana $134,187-203$ 
Wallace, L. M., Mullen, A., Johnson, P. and Verdonck, L. 2016 'Archaeological Investigations of Bourne Park, Bishopsbourne, 2011-2014’, Archaeologia Cantiana 137, 251-279

Watson, M. B. 1963: 'Iron-Age Site on Bridge Hill', Archaeologia Cantiana 78, 185-188

Webster, L. E. and Cherry, J. 1974: 'Medieval Britain in 1974', Medieval Archaeology 18, 174-223

Weekes, J. 2011: ‘A Review of Canterbury’s Romano-British Cemeteries’, Archaeologia Cantiana $131,23-42$

Weekes, J. 2016: 'Cemeteries and Funerary Practice', in M. Millett, L. Revell and Moore, A. (eds) The Oxford Handbook of Roman Britain, Oxford, 425-447

Wilkinson, P. 2000: The Swale District: an Archaeological Survey, unpublished report

Wilkinson, P. 2004-2005: An Archaeological Investigation of the Roman Aisled Stone Building at Hog Brook, Deerton Street, Faversham, Kent, unpublished report

Wilkinson, P. 2008: The Archaeological Investigation of a Hexagonal feature at Star Hill, Bridge, near Canterbury, Kent, 2003-6, unpublished report

Wilkinson, P. and Macpherson-Grant, N. 2014: 'Investigations of an Hexagonal Feature at Star Hill, Bridge, 2003-2006: Evidence of Iron Age and Earlier occupation; Anglo-Saxon Burials', Archaeologia Cantiana 135, 260-268.

Wilson, D. R. 1990: 'Air-reconnaissance of Roman Wales 1969-88' in B. Burnham (ed.) Conquest, Co-Existence and Change: Recent Work in Roman Wales, Lampeter, 10-18

Winbolt, S. E. 1925: Roman Folkestone. A Record of Excavation of Roman Villas at East Wear Bay, with

Speculations and Historical Sketches on Related Subjects, London

Wright, T. 1845: 'Proceedings of the Central Committee of the British Archaeological Association', Archaeological Journal, 1, 246-266

Young, T. P. 2012: Geophysical Surveys in Caerleon, Newport, 2007-2011, unpublished report 